\title{
Politycy i żołnierze Spór Karla Hoefera i Bernharda Hülsena o znaczenie bitwy o Górę św. Anny podczas III powstania śląskiego w 1921 roku
}

Abstrakt: Po I wojnie światowej doszło do konfliktu polsko-niemieckiego o Górny Śląsk, którego apogeum było polskie powstanie w 1921 roku. W niemieckim dowództwie powstał spór podczas zwycięskiej kontrofensywy, znanej jako bitwa o Górę św. Anny. Autor pokazuje uwarunkowania polityczne podejmowanych wówczas decyzji wojskowych i skomplikowane relacje demokratycznego rządu Republiki Weimarskiej z sympatyzującymi z nacjonalistyczną prawicą oficerami.

Słowa klu czowe: Górny Śląsk, Selbstschutz, Góra św. Anny, III powstanie śląskie, Republika Weimarska, Hoefer, Hülsen, rok 1921

Bitwa o Górę św. Anny w polskiej i niemieckiej historiografii

Znaczenie bitwy o Górę św. Anny znajdowało się zawsze w centrum uwagi historyków zajmujących się dziejami III powstania śląskiego. Toczyli oni spory zarówno dotyczące przebiegu samej bitwy, jak i ostatecznej oceny jej roli dla losów Górnego Śląska po I wojnie światowej. Ostatnio wiele miejsca poświęcono także funkcjonowaniu Góry św. Anny jako symbolu regionu (miejsca pamięci) ${ }^{1}$.

${ }^{1}$ Górę św. Anny jako miejsce, wokół którego toczy się jeden z najważniejszych polsko-niemieckich sporów politycznych, analizowali m.in. Maximilian Eiden i Marek Masnyk (M. Eiden, M. Masnyk, Góra św. Anny, w: Historia Górnego Ślaska. Polityka, gospodarka i kultura europejskiego 
Kontrowersje zaczęły się pojawiać już w okresie międzywojennym i były związane z kolejnymi wspomnieniami uczestników tych wydarzeń. Z polskiej perspektywy szczególnie ważne były relacje polityków i dowódców wojsk powstańczych: Wojciecha Korfantego (zwierzchnika zarówno władz cywilnych powstania, jak i dowództwa wojskowego) ${ }^{2}$, Macieja Mielżyńskiego (głównodowodzącego do momentu kryzysu na froncie podczas bitwy o Górę św. Anny) ${ }^{3}$, Jana Ludygi-Laskowskiego (odpowiadającego za polskie działania wojskowe podczas walk o Górę św. Anny) ${ }^{4}$,

regionu, red. J. Bahlcke, D. Gawrecki, R. Kaczmarek, Gliwice 2011, s. 439-447). W ocenie samej bitwy obydwaj autorzy przyjęli za wiarygodny opis Hoefera, pokazując jednocześnie krytycznie kontekst polityczny, w jakim ukazywały się wspomnienia dowódców freikorpsu: „Po stronie niemieckiej ocena szturmu na Górę św. Anny pozostała niejednoznaczna. Cel, czyli »wyzwolenie» okręgu przemysłowego, nie został osiągnięty. Wspomnienia kombatanckie i popularne opisy obfitują w gorzkie zarzuty pod adresem kierowanego przez Hoefera dowództwa głównego Selbstschutzu w Głogówku, a przede wszystkim pod adresem znienawidzonego demokratycznego rządu w Berlinie. Wiązały się one z legendą drugiego "ciosu w plecy «". Ibidem, s. 442. Górę św. Anny jako miejsce pamięci analizowała także Juliane Haubold-Stolle (J. Haubold-Stolle, Der heilige Berg Oberschlesiens. Der Sankt Annaberg als Erinnerungsort, w: Schlesische Erinnerungsorte, hrsg. M. Czapliński, H.-J. Hahn, T. Weger, Görlitz 2005, s. 201-220; Eadem, Góra św. Anny - sporne serce Górnego Śląska, w: Leksykon mitów, symboli i bohaterów Górnego Śląska XIX-XX wieku, red. B. Linek, A. Michalczyk, Opole 2015, s. 397-399), podkreślając, że w okresie międzywojennym najpierw to miejsce stało się ogólnoniemieckim symbolem niesprawiedliwego ustalenia granic Rzeszy po I wojnie światowej (stworzenie na wschodzie tzw. krwawiącej granicy), a po dojściu Hitlera do władzy w 1933 roku nastąpiła wręcz sakralizacja tego miejsca, odrzucenie jego chrześcijańskiej tradycji i uznanie za miejsce narodowego „przebudzenia” po 1918 roku. Zmieniono wtedy nawet nazwę wzniesienia: z Góra św. Anny - Sankt Annaberg na Góra Anny - Annaberg. Por. J. Haubold-Stolle, Góra św. Anny..., s. 397.

${ }^{2}$ W ostatniej biografii Wojciecha Korfantego Wojciech Józef Krzyk i Barbara Szmatloch (J. Krzyk, B. Szmatloch, Korfanty, silna bestia, Katowice 2020, rozdz. Bunt i rozejm) piszą, że dla Korfantego najważniejszym skutkiem bitwy była sytuacja wewnętrzna w polskim dowództwie i dramatycznie rozgrywający się kryzys w Grupie Wschód. W czasie bitwy o Górę św. Anny koncentrował się przede wszystkim na zreorganizowaniu dowództwa, rozczarowany prowadzeniem działań militarnych.

${ }^{3}$ Maciej Mielżyński, zajmujący w czasie pierwszej fazy bitwy o Górę św. Anny stanowisko dowódcy wojsk powstańczych (M. Mielżyński [Nowina-Doliwa], Wspomnienia i przyczynki do historji III-go powstania górnoślaskiego, Mikołów 1931), w swoich wspomnieniach podaje sprzeczne informacje o rozpoznaniu planów niemieckich. Najpierw twierdzi, że kontrowersje między Hoeferem a Hülsenem były znane polskiemu dowództwu, ale że doszło do porozumienia obydwu niemieckich oficerów („w kwaterze niemieckiej dwa ścierające się ze sobą obozy, z których jeden (Hoefera) był za wyczekiwaniem aż Niemcy uzyskają mandat wkroczenia na Śląsk od interaliantów, a drugi (Hülsena), który był rzecznikiem aktywnej działalności oddziałów niemieckich, uzgodniły swe poglądy i postanowili z całą siłą uderzyć na wojska powstańcze”. Ibidem, s. 134). Później zaś pisze, że atak niemiecki był niespodziewany („Dnia 21 maja o godz. 4 -tej rano uderzyli niespodziewanie Niemcy od Gogolina i Krapkowic w kierunku na front grupy wschodniej i południowej części grupy północnej”. Ibidem, s. 136).

${ }^{4}$ J. Ludyga-Laskowski, Zarys historii trzech powstań śląskich, 1919 - 1920 - 1921, WarszawaWrocław 1973, s. 274 i n. 
a także dowódców Grupy Wschód, na której odcinku znalazły się atakujące oddziały, w tym zwłaszcza Michała Grażyńskiego (szefa sztabu) ${ }^{5}$. W okresie międzywojennym bitwę o Górę św. Anny analizowali również dowódcy niemieccy, przede wszystkim Karl Hoefer i Bernhard Hülsen; także wielu innych uczestników walk po stronie niemieckiej w swoich publikowanych wspomnieniach koncentrowało się na tym wydarzeniu6 6 .

Po II wojnie światowej pojawiły się opracowania opisujące znaczenie bitwy już w o wiele szerszym kontekście historycznym, przede wszystkim były to jednak publikacje polskie ${ }^{7}$, zdecydowanie rzadziej niemiec-

${ }^{5}$ Michał Grażyński już jako wojewoda śląski, pozostając w latach 30. XX wieku w ostrym sporze z Korfantym, gloryfikował czyn zbrojny, w tym i działania Grupy Wschód w czasie bitwy o Górę św. Anny. Potępiał „zimne polityczne kalkulacje”. Mimo że nie dokonał szczegółowej wojskowej analizy ofensywy niemieckiej, to w 10. i 15. rocznicę bitwy o Górę św. Anny pisał o zwycięstwie, które osiągnęli walczący powstańcy, a nie politycy. Por. M. Grażyński, Walka o Śląsk (fragmenty wspomnień) sierpień 1920-czerwiec 1921, Katowice 1931; Idem, Walka o Śląsk (fragmenty wspomnień), „Powstaniec Śląski” 1936, nr 5, s. 4-7.

${ }^{6}$ Por.: K. Hoefer, Oberschlesien in der Aufstandszeit 1918-1921. Erinnerungen und Dokumente, Berlin 1938, s. 142-254; B. v. Hülsen, Der Kampf um Oberschlesien. Oberschlesien und sein Selbstschutz, Stuttgart 1922, s. 30-41; H. Katsch, Der oberschlesische Selbstschutz im dritten Polenaufstande, Berlin-Leipzig 1921; P. Heydebreck, Wir Wehr-Wölfe, Leipzig 1931; W. v. Oertzen, W. Petersen, Kamerad, reich mir die Hände. Freikorps und Grenzschutz, Baltikum und Heimat, Berlin 1933, s. 274 i n.; H. Zitt, Sturm auf den Annaberg. Mit dem Freikorps Oberland in Oberschlesien, Götersloh [1933]; A. Mohaupt, Kampf um den Annaberg. Tagebuch eines Sekundaners, Berlin 1936. Wiele wspomnień uczestników bitwy ukazywało się w zbiorowych wydaniach, mających charakter wyraźnie propagandowy, np.: E. v. Salomon, Das Buch vom deutschen Freikorpskämpfer, Berlin 1938 (działań niemieckich na przełomie maja i czerwca 1921 roku dotyczą teksty: Hermanna Katscha, Friedricha Glombowskiego, Viktora Scheffela, mjr. Schneppera, Rudolfa Wolffa; ibidem, s. 261-291). Podobny, wyraźnie rocznicowy i propagandowy charakter miały wspomnienia ukazujące się w czasopiśmie poświęconym historii freikorpsów - „Der Reiter gen Osten” (przede wszystkim rocznicowe numery w maju 1936 i 1937 roku poświęcone Górnemu Śląskowi z tekstami: Bernharda Hülsena, Theodora Tüllmanna, Viktora Scheffela i Vinanda Gralki, uzupełnione opisami operacji wojskowych i spisem poległych).

${ }^{7}$ Na powojennych polskich opiniach o ofensywie niemieckiej najbardziej chyba zaciążyło stanowisko Kazimierza Popiołka, który w syntezie historii Śląska pisał, że 21 maja Niemcy osiągnęli wprawdzie sukces, ale ich zasadniczy cel, wejście w głąb regionu przemysłowego, nie został osiągnięty, podobnie po wznowieniu ataku 3 czerwca. Jak pisał polski historyk, stało się tak, ponieważ: „U bram centralnego okręgu przemysłowego zatrzymała ich bohaterska, nieustępliwa postawa śląskiego powstańca" (K. Popiołek, Historia Śląska od pradziejów do 1945 roku, Katowice 1972; cyt. za wyd. 2 popr. z 1979, s. 550-551). Taka ocena niemieckiej ofensywy (K. Popiołek po raz pierwszy zaprezentował ją w opracowaniu: Trzecie powstanie śląskie, Katowice 1946; wyd. 2 - 1971) była podzielana przez większość autorów polskich piszących o skutkach operacji niemieckiej; por.: W. Ryżewski, Organizacja i rola sztabów powstańczych w III powstaniu śląskim, „Studia i Materiały z Dziejów Śląska" 1963, nr 5, s. 481-504; M. Wrzosek, Bitwa pod Górą św. Anny, 21 V-4 VI 1921, „Mówią Wieki” 1966, nr 9; A. Kwiatek, Walki w rejonie Góry św. Anny w 1921 r., w: Szkice z dziejów Leśnicy, red. F. Hawranek, Opole 1977, s. 91-107. 
$\mathrm{kie}^{8}$. Znacznie mniej było prac analitycznych, w których starano się dokonać oceny wojskowej całej operacji. W Polsce dopiero w rocznicę 40-lecia III powstania śląskiego i plebiscytu powrócono do badań szczegółowych nad bitwą. Nadal dominowało przekonanie, że to nie natarcie niemieckie, lecz błędy polskiego dowództwa były przyczyną porażki, chociaż nie używano terminów „przegrana” czy „klęska”. Za błędy uznawano: rozkaz o wycofaniu się na prawy brzeg Odry, brak wsparcia dla ofensywy w kierunku Gogolina i Krapkowic, nieskoordynowanie kontrofensywy mającej na celu odzyskanie Góry św. Anny. Nie brakowało i ocen personalnych. Idąc za opisami dowódców sympatyzujących przed II wojną światową z sanacją, Franciszek Biały pisał na początku lat 60. XX wieku, że to błędy Korfantego doprowadziły do sukcesu Niemców pod koniec maja 1921 roku?.

Zwrotem w polskich badaniach była wydana w latach 70. praca Wacława Ryżewskiego. Autor starannie przeanalizował w niej przebieg III powstania śląskiego, w tym bitwę o Górę św. Anny, której poświęcił ostatni, szósty rozdział i którą nazywał bitwą obronną. Wspomniał też o trwających wówczas w obozie niemieckim sporach, opierał się przy tym przede wszystkim na drukowanych opracowaniach Hoefera i Hülsena oraz dokumentach polskich. Ryżewski był zwolennikiem tezy o starannie przygotowanej sztabowo i zaakceptowanej przez głównodowodzącego niemieckiej Samoobrony (Selbstschutz Oberschlesien — SSOS) Karla Hoefera niemieckiej operacji wojskowej przeprowadzonej na szeroką skalę. Oficer ten miał zaakceptować plan ofensywy i po początkowych wahaniach wyznaczyć na jej wykonawcę Hülsena ${ }^{10}$. Polski historyk uważał, że wznowiona 3 czerwca operacja także

${ }^{8}$ Do końca lat 80 . XX wieku były to albo nadal dość pobieżne opisy oparte na przedwojennych wspomnieniach uczestników tych walk (por. B. Eiden, Die Operation „Tannenberg”. Das letzte größere Gefecht des oberschlesischen Selbstschutzes am 4. Juni 1921, „Schlesien” 1981, Nr. 26, s. 89-98), albo niewielkie wzmianki w popularnych, syntetycznych opracowaniach historii Śląska: Heinrich Bartsch pisał np. o jednolitej woli Niemców górnośląskich przystąpienia do walki po wybuchu powstania oraz o bezproblemowym wyborze po porozumieniu z Berlinem Hoefera na dowódcę Selbstschutzu, z którym współpracował lojalnie Hülsen. Pod dowództwem Hoefera odbyła się, zdaniem tego autora, bitwa o Górę św. Anny, a zatrzymanie niemieckiej ofensywy nastąpiło na wyraźny rozkaz Henriego Le Ronda (H. Bartsch, Geschichte Schlesiens. Land unterm schwarzen Adler mit dem Silbermond. Seine Geschichte, sein Werden, Erblühen und Vergehen, Augsburg 1985 (tutaj wyd. 2 - Würzburg 1985, s. 283). Z kolei opis Konrada Fuchsa w historii Śląska wydanej w ramach serii Deutsche Geschichte im Osten Europas nie zawiera nawet wzmianki o sporach w niemieckim dowództwie podczas bitwy o Górę św. Anny. Autor pisze tylko, że zahamowano marsz polskich powstańców na zachód i że było to zasługą Hoefera stojącego na czele Selbstschutzu (K. Fuchs, Vom deutschen Krieg zur deutschen Katastrophe (1866-1945), w: Deutsche Geschichte im Osten Europas. Schlesien, hrsg. N. Conrads, Berlin 1994, s. 621-622).

9 F. Biały, Powstania śląskie w perspektywie czterdziestolecia, „Zaranie Śląskie” 1961, z. 4, s. $840-841$.

10 „Dziś jest już wiadomo, że uderzenie na centralnym kierunku operacyjnym przygotowywane metodycznie z dużym nakładem sił i środków winno być sygnałem wywoławczym do podjęcia przez Niemców ofensywy na szerokim froncie. [...] Nieprzypadkowo więc dowodzenie nad oddziałami 
odbyła się za wiedzą i z aprobatą Hoefera (Ryżewski przywołał jako dowód książkę dowódcy Selbstschutzu z 1938 roku), a nawet że ofensywa w kierunku regionu przemysłowego została nieoficjalnie zaakceptowana przez oficerów brytyjskich i włoskich ${ }^{11}$.

Wydawać by się mogło, że przy tak rozległym stanie badań w sensie czysto faktograficznym niewiele jest już do powiedzenia na ten temat. A mimo to, kiedy zadamy pytania podstawowe dla operacji wojskowej o podobnej skali i znaczeniu, jak ofensywa niemiecka z przełomu maja i czerwca 1921 roku, nie potrafimy nadal precyzyjnie odpowiedzieć: kiedy opracowano plan bitwy; kto był autorem planu sztabowego; jakie cele wyznaczono dla operacji przed jej rozpoczęciem; jak zmieniły się te założenia po zajęciu Góry św. Anny.

Spór o autorstwo tego niewątpliwego sukcesu niemieckiego rozpoczął się natychmiast po zakończeniu walk o Górny Śląsk w 1921 roku, a głównymi adwersarzami byli: dowódca SSOS Karl Hoefer (fot. 1$)^{12} \mathrm{i}$ jego bezpośredni podkomendny, dowódca Grupy Południe (Gruppe Süd) SSOS - Bernhard Hülsen (fot. 2) ${ }^{13}$.

wydzielonymi do przeprowadzenia operacji na kierunku gogolińsko-ujazdowskim [sic!, a więc Ryżewski uważał, że od początku operacja miała na celu wejście do górnośląskiego regionu przemysłowego - R.K.] objął osobiście gen. Hülsen, za aprobatą gen. Hoefera. Miała to być popisowa, rozstrzygająca akcja pacyfikacyjna nad śląskimi powstańcami. Rzecz jasna w tej sytuacji decyzja Centrali wrocławskiej Selbstschutzu z 17 maja [dzisiaj wiemy, że takiej decyzji na poziomie politycznym nie było do czasu przybycia Brytyjczyków - R.K.] w sprawie podjęcia rychłej ofensywy była niejako zwykłą formalnością". W. Ryżewski, Trzecie powstanie śląskie 1921. Geneza i przebieg działań bojowych, Warszawa 1977, s. 357-358.

${ }^{11}$ Ibidem, s. 405.

${ }^{12}$ Karl Hoefer (1862 - 1939), ur. w Pszczynie na Górnym Śląsku, jego ojciec był z zawodu aptekarzem, matka pochodziła z pobożnej ewangelickiej rodziny. Hoefer był oficerem armii niemieckiej, w czasie I wojny światowej dowódcą pułku (został ciężko ranny w 1915 roku), potem dowódcą 117. Dywizji Piechoty. Po zakończeniu I wojny światowej w 1919 roku został dowódcą Grenzschutzu w rejencji opolskiej, a potem 32. Brygady Reichswehry; w 1920 roku mianowano go na komendanta wojskowego Wrocławia. Pod koniec służby otrzymał stopień generalski (Generalleutnant). W maju 1921 roku, podczas III powstania śląskiego, został dowódcą niemieckiej Samoobrony (Selbstschutz Oberschlesien). W okresie międzywojennym był oficerem w stanie spoczynku; po dojściu Hitlera do władzy wstąpił w 1936 roku do SS i uzyskał stopień SS-Oberführera. Zmarł 12 maja 1939 roku w Würzburgu. Por. W.K., General Hoefer, „Der Oberschlesier” 1939, Nr. 5, s. 309; H.T. Schmidt, Karl Hoefer, „Der Oberschlesier” 1939, Nr. 9, s. 473-475; W. Lesiuk, Hoefer Karl Julius Robert, w: Encyklopedia powstań śląskich, red. F. Hawranek et al., Opole 1982, s. 172.

${ }^{13}$ Bernard von Hülsen (1865-1950), ur. w Koźlu, pochodził z rodziny zawodowego wojskowego, jego ojciec był komendantem twierdzy Koźle. W czasie I wojny światowej Hülsen był już doświadczonym oficerem sztabowym, mającym za sobą kilkunastoletnią służbę w Sztabie Generalnym i w pułku gwardyjskim. W latach 1914-1918 był kolejno dowódcą 5. Pułku Piechoty Gwardii (odznaczył się szczególnie w czasie oblężenia Namur), a od 1917 roku dowódcą 231. Dywizji Piechoty. Po zakończeniu wojny dowodził freikorpsem uczestniczącym w tłumieniu rewolucji w Berlinie na przełomie lat 1918/1919; w 1920 roku był dowódcą 3. Brygady Reichswehry. W stan spoczynku przeszedł w stopniu generała (Generalleutnant); po wybuchu III powstania śląskiego został dowódcą 


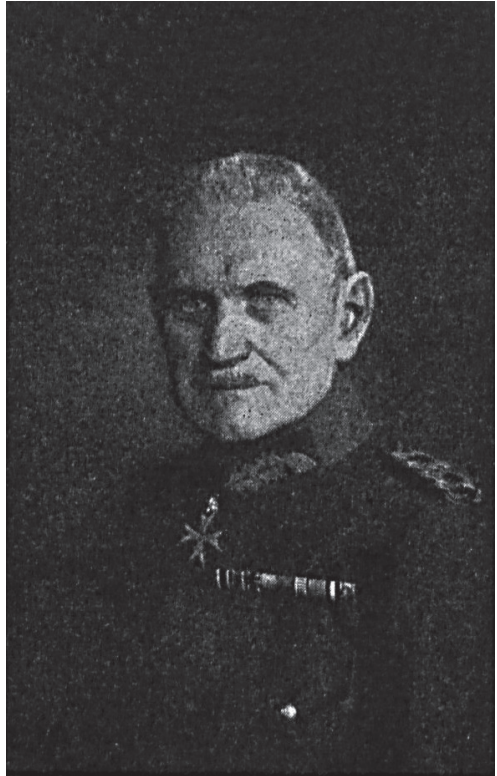

Fot. 1. Gen. Karl Hoefer

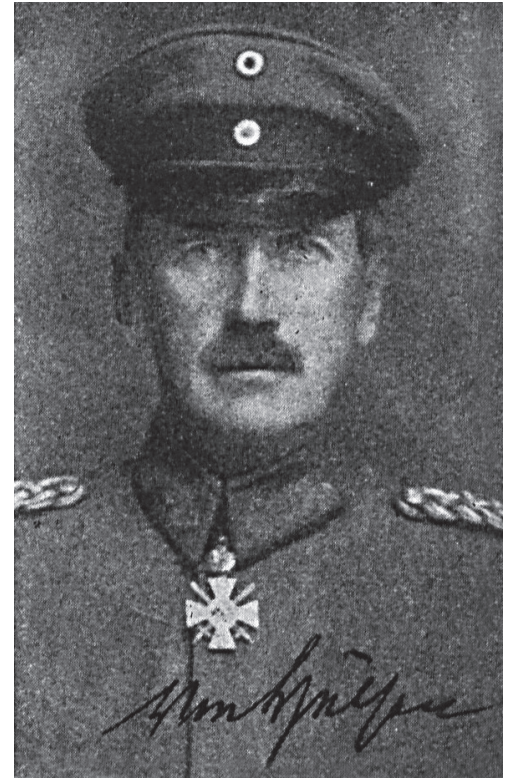

Fot. 2. Gen. Bernhard von Hülsen

Źródło fot. 1-2: „Der Reiter gen Osten: das Blatt der Kameraden Schlageters” 1937, H. 5, w zbiorach Cyfrowej Biblioteki Elbląskiej, domena publiczna: https:/dlibra.bibliotekaelblaska.pl/dlibra/publication/52923/ edition/51131/content (dostęp: 6.12.2021).

Stanowisko historyków przy rozstrzyganiu tego sporu dotychczas opiera się przede wszystkim na wzmiankowanych już drukowanych wspomnieniach obydwu niemieckich oficerów i rekonstrukcji wydarzeń na froncie polsko-niemieckim. W niemieckim Archiwum Federalnym zachowała się jednak obszerna korespondencja z lat 1936-1939, w której Hoefer i Hülsen uzasadniają — oczywiście subiektywnie - swoje decyzje podejmowane w czasie walk o Górę św. Anny. Listy, które wymieniają między sobą, nie miały być publikowane, dlatego oficerowie bardziej otwarcie niż w swoich drukowanych opracowaniach i bardziej szczegółowo przedstawiają w nich zarówno uwarunkowania, jak i własne poglądy na sporne zagadnienia. Cenna jest także dołączona do korespondencji niezależna ekspertyza wojskowa, wykonana przez specjalną placówkę działającą przy archiwum wojskowym w Poczdamie, zajmującą się przeznaczonymi najpierw dla dowództwa Reichswehry, a potem Wehrmachtu badaniami historycznymi (od 1930 roku znana jako Forschungsanstalt für Kriegs- u. Heeresgeschichte). Archiwum wojskowe w Poczdamie i jednocześnie wspomniana instytucja badawcza dysponowały obszernym zasobem archiwalnym,

Grupy Południe (Süd) niemieckiej Samoobrony (Selbstschutz Oberschlesien). Por. XX, Bernhard v. Hülsen, „Schlesische Stimme” 1940, Nr. 5-6, s. 216; Hülsen Bernhard von, Das Bundesarchiv: Akten der Reichskanzlei. Weimarer Republik online, Biographien, https://www.bundesarchiv.de/ aktenreichskanzlei/1919-1933/0000/adr/adrhl/kap1_1/para2_355.html (dostęp: 10.03.2021). 
niestety w większości dzisiaj już niedostępnym ze względu na zniszczenia spowodowane bombardowaniem z 1945 roku. Tylko niewielka część dokumentów wojskowych została uratowana, w tym wspomniana korespondencja Hoefera z Hülsenem $\mathrm{z}$ lat 30. XX wieku, dostępna współcześnie w niemieckim Archiwum Federalnym - Archiwum Wojskowym (Bundesarchiv-Militärarchiv Freiburg).

\section{Konflikt Hoefera i Hülsena podczas obchodów 15. rocznicy bitwy o Górę św. Anny}

Ożywioną korespondencję pomiędzy dwoma niemieckimi oficerami zapoczątkował artykuł Hülsena opublikowany w 15. rocznicę bitwy o Górę św. Anny w „Der Reiter gen Osten", czasopiśmie byłych freikorpslerów (fot. 3) ${ }^{14}$. Na tekst zareagował Hoefer, który już od czasu ukazania się w 1922 roku wspomnień dowódcy Grupy Południe Selbstschutzu z walk o Górny Śląsk był krytycznie nastawiony do jego wersji wydarzeń. Głównodowodzący SSOS w momencie ukazania się artykułu Hülsena był w trakcie pisania książki o walkach na Górnym Śląsku, pierwotnie miała ona nosić tytuł Land unterm Kreuz (Kraj pod Krzyżem; nawiązywał on prawdopodobnie do zrealizowanego kilka lat wcześniej niemego filmu o takim samym tytule. W filmie również dominował motyw historycznego ujęcia utraty Górnego Śląska jako odwiecznie niemieckiej ziemi, ze szczególnym uwzględnieniem historii powstań śląskich i plebiscytu, a sanktuarium na Górze św. Anny było centralnym punktem narracji).

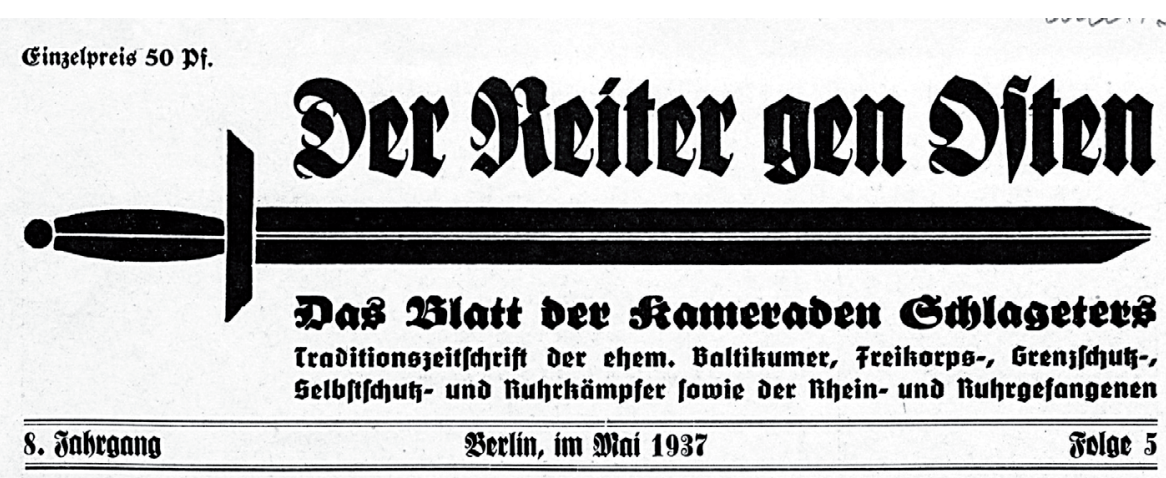

Fot. 3. Fragment strony tytułowej niemieckiego miesięcznika propagandowego „Der Reiter gen Osten: das Blatt der Kameraden Schlageters”

Źródło: „Der Reiter gen Osten: das Blatt der Kameraden Schlageters” 1937, H. 5, w zbiorach Cyfrowej Biblioteki Elbląskiej, domena publiczna: https://dlibra.bibliotekaelblaska.pl/dlibra/publication/52923/edition/51131/ content (dostęp: 6.12.2021).

${ }^{14}$ Czasopismo „Der Reiter gen Osten” ukazywało się od 1929 roku pod patronatem znanego na Górnym Śląsku dowódcy freikorpsu „Heinz” („Organisation Heinz”) - Heinza Oskara Hauensteina. 
Hülsen nie był tak dobrze znany na Górnym Śląsku jak urodzony w Pszczynie Hoefer, dowodzący górnośląską dywizją piechoty w czasie I wojny światowej, a potem Strażą Graniczną (Grenzschutzem) i brygadą Reichswehry podczas I powstania śląskiego ${ }^{15}$. O roli, jaką Hülsen odegrał podczas walk o Górę św. Anny, wiedziała tylko niewielka grupa wojskowych. Oficer boleśnie przeżywał to niedocenienie swoich zasług ${ }^{16}$. W prowadzonej przez niego w 1936 roku korespondencji prezentował się jako apolityczny dowódca wojskowy, który w odróżnieniu od Hoefera (wspieranego przez polityków współrządzącego w Niemczech Centrum) nie miał nic wspólnego z grą o Górny Śląsk. Łatwo jednak można zorientować się w jego sympatiach politycznych, które lokował po stronie niemieckiej nacjonalistycznej prawicy (w latach 30. sekundowała jej również nazistowska propaganda), z niechęcią zaś odnosił się do demokratycznych rządów tzw. koalicji weimarskiej.

W liście do Hoefera Hülsen opisał skrótowo rolę, jaką — jego zdaniem — odgrywał na Górnym Śląsku. Przyjechał na teren walk dwa dni po wybuchu III powstania śląskiego, odpowiadając na prośby kierowane do niego przez Niemców z Raciborza, obawiających się zajęcia miasta przez polskich powstańców. 5 maja przejął dowództwo nad organizującymi się dopiero oddziałami niemieckiej Samoobrony, według niego już wówczas działającymi pod nazwą: Selbstschutz - S.S.O.S. albo Gruppe Süd des oberschlesischen Selbstschutzes. Nie zaprzeczał także temu, że dowodzona przez niego formacja od początku była podporządkowana rządowej tzw. Zentrale Breslau (Centrali Wrocław). Kluczową rolę odgrywali w niej politycy, na co zresztą reagował niechętnie - jest to zrozumiałe, jeśli weźmie się pod uwagę powojenny konflikt między dowódcami freikorpsów (Hülsen został dowódcą freikorpsu już w czasie rewolucji w Berlinie na przełomie 1918 i 1919 roku) a rządem Rzeszy Niemieckiej i politykami centrolewicy. W Centrali Wrocław działał jednak ważny dla Selbstschutzu referat wojskowy, z którym współpracowano, ponieważ był pod kontrolą dowództwa wrocławskiego VI okręgu wojskowego. Za sprawy wojskowe odpowiadał w Centrali Friedrich von Schwartzkoppen, który tworzył oddziały niemieckie na terenie plebiscytowym na początku polskiego powstania. Po raz pierwszy Hülsen, organizujący Grupę Południe, rozmawiał z Schwartzkoppenem 9 maja w Nysie. Rozmowa dotyczyła szybkiej pomocy i wzmocnień kadrowych oraz materiałowych. Potem Hülsen wrócił do Raciborza, gdzie szkolił i prowadził mobilizację do oddziałów. W połowie maja jego sztab przystąpił do pierwszych prac nad planem niemieckiej kontrofensywy, która później zostanie nazwana bitwą o Górę św. Anny.

${ }^{15}$ Szczegółowo na temat działalności Grenzschutzu na Górnym Śląsku w 1919 roku por. R. Kaczmarek, Straż Graniczna (Grenzschutz), w: Stownik powstań śląskich, t. 1: I powstanie śląskie sierpień 1919, red. M. Fic, R. Kaczmarek, Katowice 2019, s. 287-289.

${ }_{16}$ Bundesarchiv-Militärarchiv Freiburg (dalej: BA MA), RH 61, sygn. 17, k. 1-18, Generalltn. a.D. von Hülsen, Hammer b. Schliersee, August 1936. 
Głównym powodem oburzenia Hoefera nie były jednak wątpliwości co do zasług Hülsena dotyczących organizacji Selbstschutzu ${ }^{17}$, lecz jego stwierdzenie: „wiadomo powszechnie, że walki o Górę św. Anny zostały poprowadzone przez Grupę Południe Selbstschutzu wbrew woli naczelnego dowództwa" ${ }^{18}$. Tego sądu dotyczyła właśnie ożywiona wymiana listów między oficerami, w których Hoefer zajmował wyraźnie pozycję defensywną, starając się odpierać argumenty Hülsena. Dowódca niemieckiej Samoobrony najczęściej pisał, że byłoby niepożądane roztrząsanie tego sporu w prasie, bo szkodzi to etosowi korpusu oficerskiego. Jednak Hülsen nie miał zamiaru paktować, zażądał nawet zwołania oficerskiego, honorowego sądu arbitrażowego, jeżeli nie zostanie mu przyznane odpowiednie dla jego roli miejsce w ocenie walk na Górnym Śląsku w 1921 roku. Hoefer ustąpił w końcu i zgodził się - by uniknąć rozprawy przed sądem oficerskim - żeby rację obu stron rozstrzygnęła niezależna placówka badawcza działająca przy archiwum wojskowym w Poczdamie.

Różnice stanowisk obu oficerów dotyczyły kilku spraw. Pytania, na które mieli odpowiedzieć historycy wojskowi w Poczdamie, odnosiły się do następujących zagadnień omówionych w dalszej części artykułu.

Czy Hoefer podejmował decyzje samodzielnie, czy był uzależniony od rządu Rzeszy Niemieckiej?

Hülsen w wielu miejscach swej korespondencji podkreślał ciągłe konflikty, do jakich dochodziło między nim a rządem Rzeszy Niemieckiej albo Centralą Wrocław, gdy chciał uzyskać wsparcie dla działań czysto wojskowych. Po przybyciu Hülsena na Górny Śląsk i po jego spotkaniu z dowódcą bawarskiego freikorpsu Oberland mjr. Ernstem Horadamem szczególnie ważne było - w ocenie oficera - przekonanie polityków we Wrocławiu, że konieczne jest umożliwienie swobodnego transportu oddziałów podążających z Bawarii na obszar plebiscytowy. W niektórych landach, zwłaszcza w Saksonii, władze krajowe nie godziły się bowiem na przejazd oddziałów z bronią ${ }^{19}$. Hülsen wymógł zniesienie tego zakazu, co umożliwiło sformowanie trzech batalionów Oberlandu, które odegrają potem kluczową rolę w ofensywie 21 maja. Świadkami jego trudnych rozmów ze Schwartzkoppenem, oprócz Horadama, byli także inni oficerowie ze sztabu Grupy Południe.

Zgoda na sprowadzenie Oberlandu nie oznaczała włączenia tych oddziałów do walki. Dowództwo wrocławskiego VI okręgu wojskowego do połowy maja kategorycznie zabraniało ataków na powstańców, a akceptowało wyłącznie działania obronne. Hülsen twierdził, że tylko dzięki niemu oraz wsparciu, jakie uzyskał od nowego delegata niemieckiego, hrabiego Hansa Praschmy (po ustąpieniu Hermanna

\footnotetext{
${ }^{17}$ BA MA, RH 61, sygn. 17, k. 19-21, Generalltn. a.D. Hoefer an B. v. Hülsen, Coburg 6.7.1936.

${ }^{18}$ Ibidem, k. 19.

19 Szerzej o tych problemach Oberlandu z dotarciem na Górny Śląsk zob. R. Kaczmarek, Powstania śląskie 1919-1920-1921. Nieznana wojna polsko-niemiecka, Kraków 2019, s. 409 i n.
} 
von Hatzfelda od 12 maja reprezentował Niemcy przy Międzysojuszniczej Komisji Rządzącej i Plebiscytowej - MKRiPleb), sztab we Wrocławiu zgodził się na podjęcie energiczniejszych działań i wysyłanie stałych patroli, by móc wyprzedzić ewentualne polskie ataki.

Hülsen, zanim jeszcze spotkał się z Hoeferem, nie miał więc wątpliwości, że stanowisko rządu Rzeszy Niemieckiej było defensywne. W 1936 roku pisał o tym następująco: „Wtedy [podczas rozmowy z Schwartzkoppenem - R.K.] po raz pierwszy dowiedziałem się, chociaż nie do końca dokładnie, o punkcie widzenia kanclerza Rzeszy Niemieckiej [był nim wówczas dopiero co wybrany, stojący na czele centrolewicowego rządu demokratów, socjalistów i chadeków, reprezentujący katolicką partię Centrum - Joseph Wirth; jego gabinet działał pod presją konieczności przyjęcia spłaty obliczonych właśnie odszkodowań wojennych, tzw. ultimatum londyńskiego - R.K.], którego zamiarem było stworzenie Selbstschutzu dla celów politycznych, ale pod warunkiem niewykorzystywania go do ofensywnych działań militarnych. W takim przypadku doszłoby [zdaniem Wirtha - R.K.] do wojny Niemiec z Polską, a nawet także może z Francją"20.

Pierwsze negatywne doświadczenia związane z kontaktami z politykami rządowymi Hülsen miał zatem jeszcze przed konfliktem z Hoeferem, chociaż był pewny, że jego późniejszy dowódca od samego początku podzielał stanowisko polityków i rozwiązanie kwestii górnośląskiej widział tylko na drodze dyplomatycznej. W tym przekonaniu utwierdziła Hülsena opublikowana przez Hoefera 22 maja 1921 roku proklamacja skierowana do Selbstschutzu („Der Kampf um Oberschlesien”). Oceniał ją jako zbyt kompromisową, zakładającą z góry pasywność w działaniach militarnych (wspominano w niej o konieczności zachowania ostrożności przy atakach na powstańców ze względu na dobro całej ojczyzny i zapowiadano, że dopiero zaangażowanie MKRiPleb pozwoli na wspólne działanie i zasadniczą zmianę sytuacji: „W krótkim czasie obok siebie walczące oddziały niemieckie i Ententy wypędzą powstańców" ${ }^{21}$ ). Hülsen pisał, że nawet nie trzeba było długo bronić stanowiska, iż taka proklamacja w połowie maja była błędem, bo potwierdził to późniejszy przebieg wypadków. Autorzy tej taktyki, w mniemaniu Hülsena byli nimi Schwartzkoppen i Hoefer, w porozumieniu z rządem Rzeszy Niemieckiej nie potrafili do takiego stanowiska przekonać nawet leciwego, legendarnego po stronie niemieckiej dowódcy oddziałów górnośląskich, także o wielkim autorytecie wśród weteranów I wojny światowej - gen. Arnolda Lequisa. Na spotkaniu, które odbyło się w pierwszej dekadzie maja w Niemodlinie, gen. Lequis, m.in. z powodu braku możliwości swobodnego działania oddziałów Selbstschutzu, odmówił przejęcia dowództwa nad formującą się niemiecką Samoobroną, co otworzyło drogę do objęcia tego stanowiska Hoeferowi. Dowódca Grupy Południe nie krył w korespondencji roz-

\footnotetext{
${ }^{20}$ BA MA, RH 61, sygn. 17, k. 2, Generalltn. a.D. von Hülsen, Hammer b. Schliersee, August 1936.

${ }^{21}$ Ibidem.
} 
czarowania, że nie został wówczas dowódcą całego Selbstschutzu, chociaż - jak sądził - miał przewagę doświadczenia wojskowego i zajmowanych podczas I wojny światowej stanowisk (w odróżnieniu od Hoefera Hülsen przez kilkanaście lat służył w Sztabie Generalnym).

Hülsen w połowie maja był już przekonany o konieczności przejścia do szybkiego ataku wyprzedzającego skierowanego przeciwko polskim powstańcom w kierunku Gogolin-Krapkowice. Na południu wsparcia Niemcom udzielali Włosi, Hülsen utrzymywał dobre stosunki z ich dowódcą - płk. Filippem Salvionim, a także Anglicy. Trzeba to było wykorzystać, by odblokować jak najszybciej górnośląski okręg przemysłowy i uwolnić istniejący tam niemiecki potencjał demograficzny i gospodarczy, a także potwierdzić siłą niemieckie zwycięstwo w plebiscy$\mathrm{cie}^{22}$. Hülsen również głośne przemówienie brytyjskiego premiera Davida Lloyda George’a w Izbie Gmin (znane w Niemczech jako przemówienie fair play) traktował jako zachętę do bardziej zdecydowanych działań wojskowych. Anglicy, w jego opinii, wyraźnie sugerowali, że nie ma zagrożenia dla Rzeszy Niemieckiej, bo ta nie miała przecież władzy suwerennej nad terenem plebiscytowym. Berlin przekazał ją w 1920 roku MKRiPleb i oddziały Selbstschutzu, przynajmniej oficjalnie, nie podlegały Reichswehrze. Można było więc działać swobodnie, bez narażania interesów Niemiec, na które ciągle powoływał się Hoefer. To alianci mieli problem, wraz z władzą przejęli bowiem obowiązek zapewnienia bezpieczeństwa mieszkańcom obszaru plebiscytowego, a nie potrafili tego zrobić ${ }^{23}$. Hülsen twierdził, że przed bitwą o Górę św. Anny takie było stanowisko nie tylko jego, lecz także wszystkich innych oficerów i żołnierzy podległych mu oddziałów w Grupie Południe, a nawet wśród większości zmobilizowanych w dwóch pozostałych grupach SSOS: Nord i Mitte.

Problemy polityczne spowodowały, że rozpoczęte w połowie maja prace sztabowe nad atakiem w kierunku Masywu Chełmskiego były utrzymywane w tajemnicy. Według Hülsena dopiero w wyniku przecieku informacji Schwartzkoppen dowiedział się, jednak bez szczegółów, o planowaniu jakiegoś ataku i interweniował w tej sprawie u szefa sztabu Grupy Południe - mjr. von Löwenfelda. Uzyskał wówczas uspokajającą odpowiedź, że chodzi o dozwolone przez aliantów patrole.

Decydujący rozkaz o rozpoczęciu operacji wydano po naradzie sztabu Hülsena w Pawłowiczkach (koło Polskiej Cerekwi) 19 maja. Nakazywano natychmiastową (bez porozumienia z Hoeferem, który wracał dopiero z rozmów w Berlinie) koncentrację przed wyznaczonym na następny dzień atakiem, który miał wyjść z rejonu Krapkowic na prawy brzeg Odry.

Kto wydał rozkaz ataku na Górę św. Anny?

Na 20 maja Hülsen zwołał naradę dowódców na zamku w Krapkowicach, ówczesnej kwaterze głównej Selbstschutzu. Kiedy dowódca Grupy Południe tam dotarł,

\footnotetext{
${ }^{22}$ Ibidem, k. 3.

${ }^{23}$ Ibidem.
} 
na miejscu był już Hoefer, który zdecydowanie sprzeciwiał się akcji przygotowanej przez sztab Hülsena. Doszło wówczas do pierwszej rozmowy obu oficerów w cztery oczy (informacje o jej przebiegu są wobec tego oparte tylko na ich, sprzecznych notabene, relacjach), podczas której Hoefer zarzucił Hülsenowi narażanie na szwank autorytetu kanclerza Rzeszy Niemieckiej i osłabienie jego pozycji w delikatnych rozmowach z partnerami europejskimi w sprawie odszkodowań wojennych. Podkreślił, że Selbstschutz jest formacją, która musi się podporządkować niemieckiemu kanclerzowi. Hülsen odmówił odwołania operacji, której wykonanie już nakazał rozkazami z 19 maja. Twierdził, że straciłby autorytet wśród żołnierzy. Miał powiedzieć: „ten atak przeprowadzę [...] niezależnie od okoliczności”24.

Hoefer, żeby przełamać impas, zaproponował wówczas ograniczenie skali operacji i zgodził się przekazać takie swoje stanowisko oficerom czekającym w drugim pokoju na rezultat rozmów. Potwierdzają to wszystkie znane relacje. Jednak jego plan został według Hülsena przyjęty lodowato, tym bardziej że Hoefer nie przedstawił zaproponowanej ograniczonej operacji z wszystkimi sztabowymi szczegółami technicznymi, lecz tylko jako ogólną ideę, a potem pośpiesznie opuścił spotkanie. Rozkazy i zadania dla poszczególnych oddziałów zmienił dopiero Hülsen. Zapowiedział przy tym, że ofensywa niemiecka nie powinna się zakończyć na wyznaczonych ograniczonych celach. Sami dowódcy będą mogli ocenić sytuację taktyczną po udanym ataku i - jeżeli będzie to możliwe - nie zatrzymają się pod Masywem Chełmskim, tylko wypchną z Góry św. Anny stacjonujące tam oddziały polskie. Te dyrektywy Hülsena $\mathrm{z}$ wieczora 20 maja potwierdzały oficerom grupy uderzeniowej, że następnego dnia będzie chodziło nie o rozszerzenie przyczółka za Odrą, lecz o pierwotnie zaplanowany atak na dużą skalę, a słowa Hoefera o ograniczeniu ofensywy to tylko rodzaj taktycznej gry. Jeden z oficerów rozczarowanych początkowo reakcją głównodowodzącego Selbstschutzu miał nawet na tej części narady powiedzieć: „No, teraz nareszcie rozumiem, wszystko zostaje po staremu [czyli sprzed rozmowy z Hoeferem - R.K.]"25.

Kiedy 21 maja oddziały niemieckie po przekroczeniu Odry szybko podeszły pod Masyw Chełmski, Hülsen udał się do dowództwa swojego lewego skrzydła, a ściślej do Horadama, i tam formalnie wydał kolejny rozkaz uzasadniony nową sytuacją taktyczną — zajęcia Góry św. Anny. W dzienniku bojowym dla kamuflażu zapisano, że do atakujących oddziałów przybył dowódca Grupy Południe, żeby przypomnieć o ograniczeniu ofensywy do podejścia do podnóża góry, jednak „trwał tak gwałtowny atak, że nie można go było już powstrzymać”26. Wersję Hülsena potwierdzili potem zarówno zapisujący rozkaz pisarz sztabowy, jak i inni oficerowie sztabu.

\footnotetext{
24 Ibidem, k. 4.

25 Ibidem, k. 5.

26 Ibidem, k. 6.
} 
Relacja Hoefera o tych wydarzeniach w wielu punktach jest inna. Według niego Hülsen na spotkaniu 20 maja dopiero zaproponował swoją akcję i przedstawił ją nie jako plan sztabowy, lecz tylko ogólną ideę do rozważenia. Całe spotkanie skoncentrowane było na innym temacie - chodziło o stworzenie jednolitego dowództwa wojskowego. Hoefer był wprawdzie już głównodowodzącym niemieckiej Samoobrony, ale na zasadach „pierwszego pośród równych”; taka jego pozycja była nie do zaakceptowania po rozpoczęciu walki. By uzyskać bezwarunkowe posłuszeństwo, na spotkaniu w Krapkowicach nie chciał podejmować tematu ofensywy, bo to utrudniało mu podporządkowanie dowódców do tej pory na wpół samodzielnych oddziałów. Przystał więc bez dyskusji na ogólnikową propozycję Hülsena, ale ze względu na rozmowy z MKRiPleb od razu zaznaczył, że nie będzie firmować polityki faktów dokonanych, jak to zrobili przywódcy polskiego powstania. Może wyrazić oficjalnie zgodę wyłącznie na ograniczoną akcję, polegającą na powiększeniu dla bezpieczeństwa przyczółka na prawym brzegu Odry. Hoefer pisał, że oficerów zawiadomił o tym z ciężkim sercem, bo tak naprawdę był zwolennikiem zdecydowanego ataku na pozycje polskie.

$\mathrm{Na}$ temat tego, co ostatecznie ustalono 20 maja w Krapkowicach, będzie się później toczyć zażarta dyskusja. Hoefer twierdził dość pokrętnie, że wprawdzie nie wydał wtedy rozkazu ataku na Górę św. Anny, ale był na to zdecydowany (niem. bestimmen), chociaż tej decyzji oficerom nie przekazał (niem. erteilen). Przekonywał, że był jednak gotowy - po ewentualnym sukcesie pierwszej części ataku do dalszego marszu i nawet do zajęcia Góry św. Anny, gdyby pozwalały na to uwarunkowania wojskowe. Hoefer utrzymywał, że reszta oficerów o tym nie wiedziała, ponieważ przedstawił jasno swoje plany wyłącznie Hülsenowi w czasie rozmowy w cztery oczy. Ten zaś miał potem przekazać ustnie odpowiednie wskazówki swoim oddziałom. Zdaniem głównodowodzącego Selbstschutzu obydwaj działali wtedy w pełnym porozumieniu, zdając sobie sprawę, że oddziały niemieckie nie zostaną pod Masywem Chełmskim, ale pójdą dalej. Hoefer użył określenia, wielokrotnie później analizowanego, o zastosowaniu przez niego makiawelicznych środków do realizacji planu, o którym nie mógł przecież informować MKRiPleb ${ }^{27}$.

\section{Kto dowodził w bitwie o Górę św. Anny?}

Punktem spornym było także to, kto dowodził podczas całej operacji zakończonej zdobyciem Góry św. Anny, oraz czy naczelne dowództwo z Hoeferem jako głównodowodzącym uczestniczyło w koordynowaniu niemieckiej ofensywy. Hoefer twierdził, że po podejściu pod Masyw Chełmski grupa uderzeniowa została sformowana na nowo. Jako że stał na czele całego Selbstschutzu, a Hülsen dzień wcześniej w Krapkowicach mu się podporządkował, to właśnie on jako głównodo-

\footnotetext{
${ }^{27}$ „[...] es handelte sich für mich ja auch nur um ein etwas machiavellistisches Mittel in der Ungewissheit der I.K. gegenüber”. BA MA, RH 61, sygn. 17, k. 19, Generalltn. a.D. Hoefer an B. v. Hülsen, Coburg 6.7.1936.
} 
wodzący ponosił „pełną odpowiedzialność za operację”, również za jej ewentualne niepowodzenie. Przyznawał tylko, że zasługa i chwała z tego zwycięstwa na polu walki przypada oczywiście oficerom i żołnierzom Grupy Południe, wykonującym jego rozkazy ${ }^{28}$.

Hülsen uznał tę relację, za próbę odebrania mu lauru zwycięzcy. W sierpniu 1936 roku, w liście zatytułowanym „Wer trägt die Verantwortung für die Annabergkämpfe im Mai, Juni 1921" (Kto jest odpowiedzialny za walki o Górę św. Anny w maju-czerwcu 1921 roku) ${ }^{29}$, skierowanym do wspomnianej już instytucji badawczej w Poczdamie zajmującej się historią działań niemieckiej armii, w kilku punktach przedstawił nieprawdziwe $-\mathrm{w}$ jego ocenie - informacje przekazane przez Hoefera na temat kulis niemieckiej ofensywy. Argumenty Hoefera uznawał za nieprzekonujące i będące efektem autosugestii wiekowego już byłego dowódcy Selbstschutzu. Hülsen podkreślał stanowczo, że operacja została opracowana wyłącznie w Grupie Południe, z własnej inicjatywy oficerów jej sztabu, a ogólnikowe informacje o niej Hoefer otrzymał dopiero na skutek niedochowania tajemnicy wojskowej, co stało się przyczyną spotkania w Krapkowicach 20 maja ${ }^{30}$.

Przebieg późniejszych wypadków opisywał Hülsen inaczej. Zaprzeczał, że Hoefer w czasie rozmowy w cztery oczy miał opowiadać mu, że jest zobowiązany do przekonania MKRiPleb o konieczności przeprowadzenia operacji wojskowej mającej na celu rozszerzenie przyczółka za Odrą. Według jego wspomnień dowódca Selbstschutzu, zrażony chłodnym przyjęciem przez oficerów sztabowych, po prostu pospiesznie wyjechał i nie wydał żadnych rozkazów. Z kolei 21 maja, kiedy oddziały niemieckie dotarły na przedpole Masywu Chełmskiego, nie było żadnej ingerencji głównodowodzącego, a już w szczególności rozkazu ze strony Hoefera dla dowódcy Oberlandu, nakazującego mu marsz na północ, a potem skierowanie ataku na szczyt wzgórza. Zdaniem dowódcy Grupy Południe nie istniał żaden makiaweliczny plan, którego Hülsen miał nie zrozumieć.

Dodatkowym dowodem na bierność naczelnego dowództwa Selbstschutzu był, zdaniem Hülsena, brak dyrektyw dla grup Północ (Nord) i Mitte (Środek), by te podjęły na mniejszą skalę ataki odciążające wielką ofensywę. Grupa Południe uzyskała wsparcie tylko na prawym skrzydle od hrabiego Hyazintha Strachwitza, który z własnej inicjatywy podporządkował swój batalion Hülsenowi. Atak dotkliwie osłabiła decyzja wstrzymania transportu obiecanej wcześniej baterii, podjęta przez naczelne dowództwo już po rozpoczęciu szturmu. Artylerzyści nawet już wyruszyli, ale zostali zatrzymani rozkazem Hoefera. Jak sądził Hülsen, stało się to po interwencji Centrali Wrocław. Według niego dowódca Selbstschutzu dopiero

\footnotetext{
${ }^{28}$ Ibidem, k. 20.

${ }^{29}$ BA MA, RH 61, sygn. 17, k. 3-18, Generalltn. a.D. von Hülsen, Hammer b. Schliersee, August

${ }^{30}$ Ibidem, k. 6.
} 1936. 
po kilku latach wymyślił tłumaczenie, że poprzez zaniechanie wydania rozkazów zamierzał pozostawić Grupie Południe wolną rękę; w przeciwnym razie musiałby wydać jednoznaczną dyrektywę zatrzymania ataku. Hülsen dostrzegał w takim postępowaniu Hoefera dowód na jego kunktatorską postawę i uleganie naciskom przewodniczącego MKRiPleb gen. Henriego Le Ronda, którego nazwał „duchowym twórcą [polskiego - R.K.] powstania"31.

W drugiej fazie operacji zarzuty Hülsena dotyczyły już nie tylko gnuśności Hoefera, lecz wręcz sabotowania operacji niemieckiej. Pisał, że jego plan przewidywał doprowadzenie do dotkliwej klęski militarnej powstańców i operacyjne odciążenie niemieckiej obrony na obydwu skrzydłach — w okolicach Olesna i Raciborza, które były realnie zagrożone zajęciem przez polskich powstańców. Wyłamanie rygla w centrum polskiego frontu dawało szansę na zrealizowanie celu strategicznego: wejścia do regionu przemysłowego przez Gliwice i doprowadzenia do załamania polskiej obrony ${ }^{32}$. Tymczasem Hoefer, kierując się wyłącznie względami politycznymi, uniemożliwił 21 i 24 maja kontynuowanie zwycięskiej operacji, mimo jej pomyślnego rozwijania się po przełamaniu linii obrony przeciwnika. Zdaniem Hülsena, dowódca Selbstschutzu podjął 24 maja starania mające na celu zatrzymanie idących do przodu oddziałów Oberlandu. Głównodowodzący zakomunikował Hülsenowi, że szef sztabu Grupy Południe - mjr von Löwenfeld (w sztabie działał pod nazwiskiem Höffer, ponieważ jego brat, kpt. Wilfried von Löwenfeld, fatalnie zapisał się w pamięci zarówno polskich, jak i niemieckich Górnoślązaków w 1919 roku ze względu na represje wobec strajkujących robotników) — współtwórca planu ataku na Górę św. Anny, musi zrezygnować z powodu przeszłości politycznej swojej i swojego brata. Hülsen był przekonany, że stanowiło to tylko pretekst, a w rzeczywistości centrolewicowa Centrala Wrocław narzuciła tę decyzję albo oszukała Hoefera, sugerując mu, że istnieje konieczność polityczna usunięcia Löwenfelda. Naprawdę zaś chodziło o wyhamowanie tempa niemieckiej ofensywy przez zakłócenie pracy sztabu pozbawionego energicznego szefa. Hoefer miał nie wziąć także w ogóle pod uwagę ofert angielskich, zdaniem Hülsena, składanych przy akceptacji Włochów. 29 maja w sztabie Hülsena pojawił się angielski major Bonnet, który powołując się na delegata angielskiego w MKRiPleb Harolda Parcivala, zapewnił, że Anglicy nie mają nic przeciwko kontynuowaniu ofensywy Selbstschutzu ${ }^{33}$. Ponieważ Hoefer

\footnotetext{
${ }^{31}$ „Präsident der General Le Rond, der geistige Urheber und Förderer des Aufstandes”. Ibidem, k. 9.

${ }^{32}$ Ibidem.

${ }^{33}$ Mjr Bonnet był w MKRPleb odpowiedzialny za tzw. Policję Plebiscytową (APO). Ówczesna aktywność Harolda Parcivala spowodowana była zmianą stanowiska Londynu po przemówieniu Davida Lloyda George’a i znajduje także potwierdzenie w źródłach brytyjskich. Premier Wielkiej Brytanii starał się po swoim wystąpieniu w Izbie Gmin szybko przeforsować decyzję o wysłaniu trzytysięcznego kontyngentu żołnierzy brytyjskich. Zdaniem badacza tej problematyki, Karstena Eichnera (K. Eichner, Briten, Franzosen und Italienern in Oberschlesien. Die Interaliierte Regierungs-
} 
wątpił, by takie było prawdziwe stanowisko Anglików, zadzwonił do Parcivala i na piśmie dostał - według relacji Hülsena - potwierdzenie, w którym angielski oficer pisał, że Anglicy: „nie sprzeciwiają się oswobodzeniu niemieckich miejscowości [...] nie życzą sobie tylko generalnej niemieckiej ofensywy"34. Obydwie strony podawały później różną interpretację treści tej rozmowy. Parcival był wówczas chory, Hoefer zaś słabo znał język angielski. Te czynniki z pewnością wpłynęły na trudności w zrozumieniu intencji obu stron podczas rozmowy telefonicznej. Hoefer jednak następnego dnia wydał całkowity zakaz kontynuowania ataku, ostrzegając jednocześnie przed jakimikolwiek działaniami bez jego rozkazu.

Wznowienie ofensywy niemieckiej nastąpiło przypadkowo. Umożliwiła to polska próba kontrofensywy podjęta w okolicach Koźla. Hülsen wykorzystał ten moment i - mimo że MKRiPleb i Hoefer nakazali wstrzymanie walk — przystąpił do realizacji drugiej części swojego planu, czyli stworzenia południowego obejścia polskiego centrum frontu, nakazując marsz czołowej grupy doliną rzeki Kłodnicy: od Koźla przez Sławięcice do Ujazdu i Gliwic. Realizację planu zahamowali tym razem Francuzi, zdaniem Hülsena, do tej pory raczej (nie licząc kilku incydentów) neutralni w czasie walk na linii frontu, wówczas zaś świadomie blokujący za polską linią możliwość przemarszu na teren górnośląskiego okręgu przemysłowego. Nawet Hülsen uznał, że zaatakowanie w takiej sytuacji oddziałów francuskich byłoby szaleństwem.

Oceniając całą operację, dowódca Grupy Południe uważał, że Hoefer nie potwierdził swoich wojskowych kompetencji i nie był zdeterminowany, by przejąć odpowiedzialność za dowodzenie. Przeciwnie, całkowicie podporządkował się dyrektywom politycznym nadchodzącym z Berlina. Zdaniem Hülsena nie było wojskowych argumentów do powstrzymywania ofensywy w żadnym momencie jej realizacji. Opinie Hoefera o przewadze liczebnej powstańców i ich lepszym uzbrojeniu nie były, w jego mniemaniu, zgodne z prawdą. To Selbstschutz miał przewage i inicjatywę uzyskaną po sukcesie 21 maja. Zaprzepaszczono unikalną szansę skutecznego ataku i odzyskania kontroli nad górnośląskim regionem przemysłowym. Na powodzenie akcji miało wskazywać zarówno zwycięstwo w pierwszej fazie ofensywy, jak i nieudane polskie kontrataki, co umożliwiło szybkie dalsze przesuwanie się po 3 czerwca oddziałów niemieckich na wschód.

und Plebiszitskommission in Spiegel der britischen Akten, St. Katharinen 2002, s. 86), opierającego się na zachowanych źródłach brytyjskich, to zaangażowanie nie miało jednak polegać, jak twierdził Hülsen, na współpracy z Niemcami, ale wręcz przeciwnie - Londyn zamierzał za wszelką cenę uniknąć nowych walk na Górnym Śląsku. Rząd brytyjski uważał się za gwaranta traktatu wersalskiego i z tego powodu, tylko zgodnie z wyrażoną wolą powrotu do działania fair play, Parcival miał kontaktować się z Niemcami.

${ }^{34}$ BA MA, RH 61, sygn. 17, k. 11, Generalltn. a.D. von Hülsen, Hammer b. Schliersee, August 1936. 
Hülsen, szukając winnych wstrzymania ofensywy, obarczał odpowiedzialnością nie tylko Hoefera. Jego zdaniem za utratę Górnego Śląska należało winić na równi głównodowodzącego Selbstschutzu, jak i błędną politykę ówczesnego rządu. Twierdzenie, że rząd robił wszystko, co można, było dla Hülsena tylko usprawiedliwieniem nieudolności, a do zwycięstwa w bitwie o Górę św. Anny doszło tak naprawdę wbrew woli centrolewicowego rządu kanclerza Wirtha. To właśnie dlatego, według Hülsena, stworzono później mit o z góry przegranej walce zbrojnej o Górny Śląsk z powodu sytuacji dyplomatycznej („,rząd i generał Hoefer jednakowo byli zainteresowani budowaniem tego mitu" ${ }^{35}$ ). Hülsen wierzył zaś w możliwość rozstrzygnięcia sprawy dzięki zwycięstwu na polu walki. Jak ironicznie konstatował, to jednak dowódca Selbstschutzu - paradoksalnie — został wojennym bohaterem; nie dopuszczał do głosu swoich ówczesnych podkomendnych, chętnie za to odbierał ordery i honory zwycięzcy w bitwie o Górę św. Anny.

\section{Alfreda Stengera ocena wojskowa bitwy o Górę św. Anny}

Z tych subiektywnych rekonstrukcji wydarzeń trudno poznać ich rzeczywisty przebieg, tym bardziej że w listach obydwu niemieckich dowódców bez trudu odnaleźć można próby poszukiwania przez oficerów swego miejsca w nowej sytuacji politycznej po 1933 roku. Centrolewicowe rządy Republiki Weimarskiej były przecież uznawane przez Adolfa Hitlera za winne klęski Niemiec w walce o granice po I wojnie światowej. „Dolchstosslegende” i rewizja Wersalu stały się głównymi hasłami propagandowymi, które przyniosły sukces niemieckim nazistom. Odpowiedzialność za utratę wschodniej części Górnego Śląska przypisywana była błędom popełnionym przez socjalistów, demokratów i chadeków i doskonale pasowała do narracji zdrady interesów niemieckich, co widać w listach Hülsena. Dowódca ten opisał w nich swój konflikt z Hoeferem, ale nie zapominał za każdym razem wspomnieć o „politycznych dyrektywach” kanclerza Wirtha oraz wrocławskich centrolewicowych politykach, których kunktatorstwo doprowadziło do utraty części Górnego Śląska mimo sukcesów Selbstschutzu.

Dylemat, komu przyznać rację w tym sporze: widzącemu sytuację Górnego Śląska w szerokim kontekście politycznym Hoeferowi czy oficerowi wierzącemu, że zwycięska kampania może zmieniać sytuację polityczną, w tym przypadku miał jednak znaleźć arbitra. Hülsen, kiedy zrezygnował z żądania zwołania sądu oficerskiego, uzgodnił z Hoeferem, że sporną kwestię zinterpretuje bezstronnie wojskowy

\footnotetext{
${ }^{35}$ Ibidem, k. 15.
} 
historyk. Referentem sprawy w poczdamskim Forschungsanstalt für Kriegs- u. Heeresgeschichte został doświadczony archiwista i historyk wojskowości, wyższy radca rządowy - Alfred Stenger, autor prac analitycznych dotyczących operacji wojskowych podczas I wojny światowej (np. analizy kampanii 1918 roku na froncie zachodnim: Schicksalwende: von der Marne bis zur Besle, 1918, Potsdam 1930) ${ }^{36}$. Swoją ekspertyzę złożył 17 listopada 1936 roku. Stenger dysponował większą liczbą dokumentów i relacji niż ta, która zachowała się do dzisiaj. Mając kompetencje wojskowe, z dużą starannością dokonał oceny operacji niemieckiej w czasie III powstania śląskiego. Nie podjął się jednak odpowiedzi na kluczowe dla obydwu oficerów pytanie: na kim spoczywa odpowiedzialność za podejmowane decyzje? Uznał, że wymagałoby to dalszych, drobiazgowych poszukiwań archiwalnych, w rzeczywistości jednak zapewne nie chciał zajmować wyraźnego stanowiska politycznego.

Stenger oceny sformułował w postaci odpowiedzi na pytania, jakie zadał po zapoznaniu się z korespondencją między Hoeferem i Hülsenem i po przejrzeniu podstawowej dokumentacji archiwalnej. Poniżej zaprezentowano wnioski, do jakich doszedł.

\section{Jaki był przebieg wydarzeń do 20 maja 1920 roku?}

Zdaniem Stengera, Hoefer mimo nominacji na głównodowodzącego Selbstschutzu nie był jeszcze ostatecznie zdecydowany na przejęcie tego stanowiska przed swoją wizytą w Berlinie. Uzależnił decyzję od stanowiska Ministerstwa Obrony Rzeszy (Reichwehrministerium) i kierującego tym resortem, znanego mu zarówno ze służby w pułkach śląskich, jak i w czasie I wojny światowej, gen. Ottona Hassego. Według Stegnera ze spotkania w Ministerstwie Obrony Hoefer wyciągnął wniosek, że rząd Rzeszy Niemieckiej nie akceptuje ewentualnej niemieckiej kontrofensywy i należy odłożyć ją w czasie albo zupełnie z niej zrezygnować. Tylko dzięki takiej strategii Niemcy osiągną usunięcie polskich powstańców z zajętego terytorium; nie można wykluczyć zaangażowania do takiej akcji współpracujących z wojskami brytyjskimi oddziałów niemieckiej Samoobrony. Do tego momentu Selbstschutz miał stać $\mathrm{z}$ bronią u nogi, a walkę podjąć wyłącznie w wypadku konieczności obrony miejscowości zagrożonych polskim atakiem. Hoefer miał nawet uzyskać od Hassego informację, że angielski ambasador zasugerował, iż Brytyjczycy zostawią wówczas niemieckim oddziałom swobodę działania (Bewegungsfreiheit), nawet gdyby groziło to konfliktem wojskowym z państwem polskim. Hasse przekazując na końcu rozmowy Hoeferowi pełnomocnictwo do podejmowania samodzielnie następnych decyzji już po powrocie na Górny Śląsk, brał pod uwagę szybko zmieniającą się sytuację i liczył na rozwagę głównodowodzącego Selbstschutzu oraz jego autorytet, dający gwarancję powstrzymania niekorzystnych politycznie akcji wojskowych.

${ }^{36}$ BA MA, RH 61, sygn. 17, Oberregierungsrat bei der Forschungsanstalt für Kriegs- u. Heeresgeschichte Stenger, Gutachten, Potsdam, den 17.11.1936. 
O ile rozmowa w Ministerstwie Obrony zakończyła się przekazaniem Hoeferowi dyrektywy nie tyle rezygnacji, ile odłożenia w czasie użycia Selbstschutzu, o tyle kanclerz Wirth wydał w tym względzie jednoznaczne dyspozycje zabraniające w ogóle akcji ofensywnych. Szef rządu niemieckiego swoje nadzieje w sprawie Górnego Śląska pokładał w brytyjskich obietnicach i działaniach wyłącznie z mandatem MKRiPleb. Kanclerz Rzeszy Niemieckiej stojąc w obliczu trudnych rokowań związanych z reparacjami wojennymi i groźbami dotyczącymi okupacji zachodniej części Niemiec, zarysował pesymistyczny obraz rozwoju wypadków, gdyby do działań wojennych na dużą skalę doszło także na wschodzie państwa. Wyraził to jasno słowami: „Francja tylko czai się do napaści na Niemcy — kwestia górnośląska nie może być rozwiązana odrębnie, tak jak chce Selbstschutz; cała sprawa jest zależna od całości sytuacji [politycznej - R.K.]; oświadczenie brytyjskiego ambasadora o życzliwym [proniemieckim - R.K.] stanowisku rządu brytyjskiego względem kwestii Górnego Śląska będzie tylko aktualne wtedy, kiedy Selbstschutz zrezygnuje z działań ofensywnych" ${ }^{37}$. Wirth nie powoływał się wyłącznie, jak minister Hasse, na rozmowę $\mathrm{z}$ ambasadorem, lecz podał także inne argumenty zmuszające, w jego opinii, Niemcy do zajmowania pozycji defensywnej. Uważał, że obietnice Brytyjczyków, tym bardziej ich uzgodnienie w ramach MKRiPleb, będą realne tylko w wypadku lojalnego wypełnienia zobowiązania do unikania akcji zbrojnych Selbstschutzu. Wtedy miały się także pojawić szanse dołączenia do wojsk alianckich usuwających polskich powstańców z zajętego terytorium. Kanclerz zdawał sobie sprawę, że podział terenu plebiscytowego jest przesądzony i należy pogodzić się ze stratami terytorialnymi, trzeba je tylko minimalizować ${ }^{38}$. Wirth nie krył przed Hoeferem swojej nieufności do Selbstschutzu - jako formacji, która kontynuując tradycję freikorpsów, jest wroga centrolewicy, a więc i jego demokratycznemu rządowi. Przywoływał przykład krajów nadbałtyckich, gdzie brak kontroli nad takimi freikorpsami zakończył się katastrofą dla interesów niemieckich, a jednocześnie podważył wiarygodność rządu niemieckiego wobec aliantów zachodnich. Freikorpsy, szczególnie po doświadczeniach związanych z puczem Kappa-Lüttwitza, były dla niego zagrożeniem integralności Niemiec. O podobnie niebezpiecznym rozwoju sytuacji także na Górnym Śląsku świadczyć miały nadchodzące już skargi do Berlina na bezprawne działania Selbstschutzu. Ze strony kanclerza padła wobec tego stanowcza dyrektywa, że oczekuje się od Hoefera zdyscyplinowania oddziałów niemieckiej Samoobrony, do tej pory działających samodzielnie, podległych tylko lokalnym dowódcom ${ }^{39}$.

Niejasny dla Stengera był wynik rozmów Hoefera ze Schwartzkoppenem, reprezentującym Reichswehrę w Centrali Wrocław. Odbyły się one we Wrocławiu,

\footnotetext{
${ }^{37}$ Ibidem, k. 59.

38 „Teilung Oberschlesiens wohl unvermeidlich”. Ibidem.

${ }^{39}$ Ibidem.
} 
prawdopodobnie 19 maja, kiedy dowódca Selbstschutzu wracał z Berlina. Oficerowie z pewnością analizowali wówczas sytuację w Grupie Południe. Schwartzkoppen, który był już po rozmowie Löwenfeldem, zapewnił Hoefera, że szef sztabu Grupy Południe zaprzeczył, by na południu przygotowywano operację wojskową na większą skalę. Najwyżej prowadzono przygotowania do reakcji na nieudane polskie ataki skierowane na Gogolin-Krapkowice. Schwartzkoppen nie wykluczał niemieckiego kontrataku, ale mieszczącego się nadal w dozwolonej przez aliantów samoobronie zagrożonych atakiem polskim niemieckich miejscowości ${ }^{40}$.

Wpływ rozmów przeprowadzonych w Berlinie i we Wrocławiu widać już w pierwszej proklamacji skierowanej przez Hoefera do żołnierzy Selbstschutzu. Przedstawił w niej zadania niemieckiej formacji z dużą ostrożnością. Mimo że Samoobrona powstała przecież w celu podjęcia natychmiastowej walki z powstańcami, jej główny dowódca zalecał żołnierzom cierpliwe oczekiwanie do czasu przywrócenia porządku przez Brytyjczyków, a do tego momentu mieli stać z bronią u nogi ${ }^{41}$. Z takim też nastawieniem Hoefer 20 maja podążył do Głogówka, gdzie wyznaczył miejsce na swoją kwaterę główną. Po drodze zatrzymał się jeszcze w sztabie Grupy Środek (Mitte), gdzie odebrał pilny telefon od Schwartzkoppena, zawiadamiający, że informacje z poprzedniego dnia nie były precyzyjne i jakieś jednostki Selbstschutzu (nie wiedział dokładnie jakie i gdzie) rzeczywiście zamierzają następnej nocy zaatakować polskie pozycje. Hoefer zapewnił, że po ustaleniu, o jakie oddziały chodzi, powstrzyma ewentualny atak, zgodnie z wcześniejszymi ustaleniami. Szybko dowiedział się od jednego z oficerów w sztabie Grupy Środek (nie było to wielką tajemnicą, wszak już realizowano rozkaz Hülsena o koncentracji oddziałów w okolicach Krapkowic, o czym zapewne powiadomiono dowódców innych grup), że oddziały Grupy Południe rozpoczną atak już następnej nocy. Hoefer nie znał szczegółów operacji, ale przekazał dla dowódcy Grupy Środek płk. von Hollebena (nieobecnemu wtedy w kwaterze) rozkaz powstrzymania operacji. Potem niezwłocznie pojechał do kwatery Grupy Południe w Polskiej Cerekwi, napotykając już na drodze maszerujące w stronę Krapkowic oddziały, których żołnierze wykrzykiwali triumfalnie: „Wir stürmen den Annaberg!" 42 .

Do Polskiej Cerekwi Hoefer dotarł ok. godziny 17.30, ale nie zastał już Hülsena, który udał się do Krapkowic na zwołane zebranie dowódców. Głównodowodzący dowiedział się tylko od kwatermistrza mjr. Hansa von Hauensteina, że informacja o rozpoczęciu operacji następnego dnia rano jest prawdziwa. Do Krapkowic Hoefer przyjechał ok. 19.00, jeszcze przed Hülsenem, i zdążył zgromadzonym już na zamku dowódcom wyrazić swoje zaskoczenie faktem, że bez jego

\footnotetext{
${ }^{40}$ Ibidem, k. 60.

${ }^{41}$ „Bis dahin steht mit Gewehr bei Fuß!”. Ibidem.

${ }^{42}$ Ibidem, k. 61.
} 
wiedzy rozpoczęto akcję wojskową na dużą skalę, a ponadto świadomie wprowadzono w błąd oficerów Reichswehry w Centrali Wrocław. Zgodnie z przyjętymi dyspozycjami ostrzegł przed dotkliwymi szkodami, jakie atak może spowodować dla Niemiec. Decyzję, co należy w tej sytuacji robić dalej, odłożył do rozmowy z Hülsenem. Podobno Hülsen jeszcze przed kluczową rozmową w cztery oczy został powiadomiony o negatywnym stanowisku Hoefera do całej operacji, a jeden z jego oficerów (rotmistrz von Schaper) zaproponował uwięzienie dowódcy Selbstschutzu do momentu zakończenia ofensywy. Hülsen jednak nie zdecydował się na jawną niesubordynację i doszło do rozmowy obydwu dowódców na zamku w Krapkowicach.

Hoefer przekazał Hülsenowi wyraźne dyrektywy, które otrzymał w Berlinie i Wrocławiu. Ten się jednak nie ugiął, powtórzył zdecydowanie, że atak rozpocznie się następnego dnia rano, zgodnie z wydanymi rozkazami. Na pytanie, dlaczego nie zawiadomił o tym Centrali Wrocław, Hülsen odpowiedział, że nie musiał tego robić, bo przecież chodzi o polepszenie obecnej pozycji obrony niemieckiej. Hoefer nie mogąc wymusić na swoim oficerze rezygnacji, uznał, że lepiej będzie nie reagować na nieuchronną już akcję wojskową zaplanowaną przez Grupę Południe.

$\mathrm{W}$ tym momencie relacje obydwu oficerów stają się rozbieżne i Stenger nie potrafił rozstrzygnąć, która z nich jest bliższa prawdy. Hoefer utrzymywał, że z jego strony była to makiaweliczna gra. Hülsen zaprzeczał tej wersji; twierdził, że nie zawiadomiono go, iż chodzi o jakąś grę. Z jego rozmowy z głównodowodzącym wynikało po prostu, że ma się trzymać tylko wyznaczonej do osiągnięcia rubieży, ponieważ jej przekroczenie zaszkodzi interesom górnośląskim.

Potem Hoefer wyszedł do oficerów zebranych w pokoju obok. Tutaj także relacje dowódców się różnią. Hoefer twierdził, że to Hülsen zgromadził ich, by przekonać innych oficerów do swoich planów ofensywnych. Dowódca Grupy Południe zaś zaprzeczał, by była to jego inicjatywa. Oficerowie wrogo nastawieni do Hoefera próbowali wymusić na nim zmianę decyzji. Na spotkaniu atmosfera była bardzo napięta; podobno Hoeferowi zagrożono nawet bronią. Dopiero interwencja Hülsena, który odprowadził Hoefera do samochodu, uspokoiła sytuację.

Następnie Hülsen już sam rozmawiał ze swoimi dowódcami i potwierdził rozkaz o rozpoczęciu rankiem ataku na pozycje polskie. Dodał, by nie przekraczać wyznaczonej linii pozwalającej rozszerzyć przyczółek na prawym brzegu Odry, ale nie wprowadził tego zapisu do rozkazu.

Ocena wiarygodności relacji Hoefera i Hülsena

Zdaniem Stengera to rozmowa $\mathrm{z}$ Wirthem (raczej nie z ministrem Hasse, który dopuszczał wymuszoną okolicznościami ofensywę niemiecką) spowodowała pasywność Hoefera, który zaakceptował zachowawcze stanowisko kanclerza ${ }^{43}$. Dla niemieckiego historyka nie ulegało wątpliwości, że Hoefer był wobec tego przeciwny dzia-

\footnotetext{
${ }^{43}$ Ibidem, k. 67.
} 
łaniom ofensywnym Selbstschutzu zaproponowanym przez sztab Grupy Południe ${ }^{44}$. $\mathrm{W}$ ten sposób narastał jego konflikt $\mathrm{z}$ Hülsenem. Brak szczerości w rozmowach doprowadził także do ich wzajemnego niezrozumienia w momencie podejmowania decyzji operacyjnych. Hoefer prawdopodobnie w końcu dał się przekonać 20 maja, że manewr ofensywny za Odrą, na przedpolu Masywu Chełmskiego, jest potrzebny. Uważał jednak i dał to do zrozumienia, iż walki mają mieć miejsce na stosunkowo niewielkim terenie, tylko dla poprawienia pozycji niemieckiej obrony na przyczółku za Odrą - między Krapkowicami a Gogolinem. Wykluczał dalszą ofensywę, nawet tę mającą na celu tylko zajęcie Góry św. Anny, a tym bardziej plany dalszego marszu do górnośląskiego okręgu przemysłowego. Stenger na potwierdzenie takiej właśnie wersji zrekonstruowanych przez siebie wydarzeń do 20 maja przywołał niezachowane do dziś relacje na ten temat innych oficerów sztabu Hülsena: Löwenfelda, Schapera i Bassego, i podzielił ich oceny.

Stenger nie wierzył w makiaweliczny plan Hoefera. Nie można było zweryfikować istnienia tej strategii, ponieważ jedyny świadek, gen. Schwartzkoppen, zmarł w 1931 roku. Nawet jeżeli Hoefer myślał o takiej grze, to zdaniem Stengera pod względem wojskowym byłby to plan zupełnie chybiony. Rozkaz wydany Hülsenowi w Krapkowicach powinien być klarowny, zgodnie z generalną zasadą, że wykonujący rozkazy oficer musi je dobrze rozumieć. Przełożony powinien, nawet kiedy ma wątpliwości, czy został dobrze zrozumiany, nakazać podkomendnemu powtórzyć treść zleconego mu zadania, by mieć pewność jego wykonania. Jeżeli więc nawet doszło do nieporozumienia, a Hoefer miał inne zamiary, których klarownie nie przekazał, to i tak on jest odpowiedzialny za niekonsekwencje w dowodzeniu po 21 maja.

Czy atak 21 maja odbył się bez zgody „najwyższego dowództwa” („höchste Führung")?

Stenger uważa, że odpowiedź na tak sformułowane pytanie nie może być jednoznaczna. Po rozmowie z Hülsenem w Krapkowicach Hoefer był już pewny, że operacja rozpocznie się następnego dnia, ale sam nie wydał jasnego rozkazu zabraniającego jej podjęcia. Przyzwolenie na akcję zostało wymuszone jednak wbrew jego woli. To rozwój wypadków, których nie brał pod uwagę, kiedy prowadził rozmowy w Berlinie i we Wrocławiu, a które dawały gwarancję kontrolowania sytuacji wojskowej, spowodował jego pasywnośćc ${ }^{45}$.

W związku z najwyższym dowództwem Selbstschutzu Stenger postawił jeszcze jedno bardzo ważne pytanie. Już nie tylko z perspektywy oceny bitwy o Górę św. Anny, ale generalnie, patrząc na całokształt dowodzenia siłami niemieckimi

${ }^{44}$ „Es doch gar keinen Zweifel unterliegen, daß Genlt. Hoefer grundsätzlich gegen eine Offensive Betätigung des SSOS war, zum mindestens so lange, als nicht eine ausdrückliche »Aufmusterung « seitens der Engländer vorlag". Ibidem, k. 67.

${ }^{45}$ Ibidem, k. 72. 
podczas III powstania śląskiego, rysuje się wątpliwość, kto sprawował najwyższe dowództwo wojskowe w maju i czerwcu 1921 roku. Hoefer i inni dowódcy Selbstschutzu podkreślali wielokrotnie swoją niezależność, zarówno w chwili wyboru dowódcy formacji, jak i w momencie podejmowania decyzji operacyjnych. Stenger zaś tej pewności nie miał. Pisał, że nie wiadomo, czy „höchste Führung” to Hoefer, czy rząd Rzeszy Niemieckiej wraz z dowództwem Reichswehry. Niestety, nie rozwinął tego kluczowego wątku, enigmatycznie i mało przekonująco konstatując, że brak co do tego materiałów.

Geneza i przebieg drugiej fazy ofensywy niemieckiej, po 3 czerwca 1921 roku

Sprenger próbował ocenić w tej części swej analizy zasadność zarzutu Hülsena, jakoby Hoefer zaprzepaścił możliwość kontynuowania ofensywy niemieckiej. Głównodowodzący Selbstschutzu miał po zdobyciu Góry św. Anny postulowaną swobodę manewru (Bewegungsfreiheit), którą zapewniło mu opanowanie Masywu Chełmskiego i jego przedpola. Hoefer zaś, zamiast przygotować warunki do dalszego marszu na wschód, usunął pod wymyślonym pretekstem (może także z inspiracji Centrali Wrocław) szefa sztabu Grupy Południe, wstrzymując w ten sposób sprawne działanie sztabu Hülsena. Nie wziął też poważnie pod uwagę możliwości wykorzystania domniemanej propozycji angielskiej (kpt. Benetta), potwierdzonej przez płk. Percivala, by kontynuować ofensywę. To, że 3 czerwca operacja się jednak zaczęła, było tylko efektem szczęśliwego zbiegu okoliczności — podjęcia próby polskiej kontrofensywy w kierunku Koźla (w Polsce operacja znana jako bitwa o Kędzierzyn). Hülsenowi dało to pretekst, by ponownie bez zgody dowódcy Selbstschutzu rozpocząć atak, deklarując oficjalnie, że jest to niemiecka samoobrona przed polskim uderzeniem. Hoefer zresztą i wtedy zabronił kontynuowania działań ofensywnych, zgodził się tylko na ograniczony kontratak na Kędzierzyn i Koźle.

Także w odniesieniu do tych wypadków relacje obydwu oficerów różnią się na tyle, że Stenger nie potrafił rozstrzygnąć ostatecznie wątpliwości co do przebiegu wydarzeń. Według Hülsena gdzieś na zachód od Koźla odbyło się drugie spotkanie obu dowódców. Hülsen miał wtedy zaproponować przemarsz do górnośląskiego okręgu przemysłowego, czyli kontynuację — zaplanowanego zgodnie z ulubionym manewrem najpierw pruskich, a potem niemieckich sztabowców (odwołującym się do zwycięstwa Hannibala pod Kannami; Cannae-Schlacht) - wykonania obejścia silną grupą uderzeniową od południa. Dawałoby to również możliwość przystąpienia do ataku na północy i okrążenia wysuniętych polskich oddziałów powstańczych. Jednocześnie manewr otworzyłby drogę do Gliwic i innych wielkich miast górnośląskich (Zabrza, Bytomia, Królewskiej Huty, Katowic, Mysłowic). Hoefer jednak zaprzeczał, że takie spotkanie miało w ogóle miejsce. Nie negował natomiast, że próbował powstrzymać ofensywne zapędy Hülsena. Na zwołanej do Krapkowic naradzie dowódców Hoefer odwołał akcję i nakazał czekać na rozwój wypadków - 
to znaczy na ewentualne ponowienie przez Polaków ataku. Dopiero kiedy to nastąpiło i uzyskano kolejne potwierdzone meldunki o rozwijaniu się polskiej ofensywy w kierunku Koźla i o zagrożeniu zarówno ważnego węzła kolejowego, jak i portu rzecznego, Hoefer zgodził się na odpierający polską kontrofensywę atak. Uderzenie z rejonu Koźla-Leśnicy i z drugiego kierunku, miało na celu odciążenie głównej operacji, z rejonu Raszowej—Łąk Kozielskich. Podobnie jednak jak 21 maja i tym razem zakreślił najdalszy zasięg niemieckiego kontrataku: do linii Zalesie-Sławięcice-Dworzec w Kędzierzynie.

Jest interesujące, że atak miał nastąpić nie tyle ze względów wojskowych, które interesowały Hülsena, ile politycznych. Do sztabu Selbstschutzu docierały coraz bardziej gorączkowe prośby Niemców z Koźla, którzy obawiali się zajęcia miasta, o pomoc wojskową. Wsparli ich tym razem politycy: Praschma i Hans von Moltke w Berlinie (to zresztą bardzo ciekawy wątek utrzymywania ciągłego kontaktu między niemieckim Ministerstwem Spraw Zagranicznych - Auswärtiges Amt a Hoeferem). Obydwaj politycy interweniowali za pośrednictwem Centrali Wrocław $^{46}$.

Cała ekspertyza Stengera logicznie rekonstruuje wydarzenia związane z bitwą o Górę św. Anny, dając jednocześnie możliwość spojrzenia dzisiaj za kulisy rozgrywających się między 21 maja a 4 czerwca 1921 roku wydarzeń związanych z niemiecką ofensywą. Mimo skoncentrowania znacznych sił wojskowych przez Niemców ograniczenia międzynarodowe wykluczały — zdaniem polityków niemieckich z Berlina i Wrocławia - wielką ofensywę niemiecką. Do takiej oceny przekonano także Hoefera, który miał oczekiwać na wsparcie angielskie, chociaż te nadzieje niemieckiego ministra obrony przekazane Hoeferowi były chyba zdecydowanie przesadzone. Trudno odnaleźć choćby ślady dyplomatycznych sugestii, że Anglicy rzeczywiście mieli zamiar wykorzystać Selbstschutz do działań wojskowych i usunięcia powstańców z zajmowanego przez nich obszaru. Jeszcze trudniej wyobrazić sobie, że istniała szansa na akceptację takiej akcji ze strony MKRiPleb, której działalnością kierował sprzyjający przecież Polsce gen. Henri Le Rond.

Występujący jako główny oponent Hoefera dowódca Grupy Południe, pod którego dowództwem znajdowały się najlepsze oddziały Selbstschutzu (przede wszystkim trzy bataliony Oberlandu dowodzone przez Horadama), patrząc z perspektywy czysto wojskowej, rzeczywiście swój optymizm na powodzenie takiej operacji oceniał realnie. Jego rozważania na temat tego, czy stanowisko dowódców alianckich (głównie francuskich) byłoby pasywne, jest dzisiaj trudne do rozstrzygnięcia. Hülsen liczył na to samo, na co liczył Korfanty 3 maja, w chwili wybuchu III powstania śląskiego - mianowicie, że to fakty dokonane, a nie rozmowy dyplomatyczne ukształtują mapę polityczną Górnego Śląska. Korfanty miał jednak za sobą wsparcie Le Ronda i dlatego był skuteczniejszy. Dzisiaj wiemy, że decyzja

\footnotetext{
${ }^{46}$ Ibidem, k. 76.
} 
o podjęciu walki dała Polsce powiaty, których — odwołując się tylko do plebiscytu - Rzeczypospolitej by nie przyznano. Skutków ewentualnego wojskowego sukcesu Hülsena nie możemy zweryfikować w ten sam sposób, bo do niego po prostu nie doszło. W momencie podejścia oddziałów Grupy Południe do Ujazdu Niemcy musieli się zatrzymać. Hülsen nie mógł doprowadzić do otwartego starcia z wojskami francuskimi i podjął decyzję, zresztą nadal pod silnym naciskiem Hoefera, o wstrzymaniu dalszego marszu do Gliwic.

„Wojna jest jedynie kontynuacją polityki innymi środkami”7

Znana sentencja pruskiego oficera Carla von Clausewitza przytoczona powyżej doskonale wpasowuje się w spór niemieckich dowódców Selbstschutzu, który wcale nie zakończył się w 1936 roku. Hoefer potraktował ekspertyzę Stengera jako akceptację swojej wersji wydarzeń i otwarcie drogi do publikacji książki. Wydał ją zresztą w 1938 roku pod innym tytułem niż pierwotnie zamierzał (nie Land unterm Kreuz, lecz Oberschlesien in der Aufstandszeit 1918-21).

Podtrzymanie w publikacji Hoefera wersji wydarzeń, która została podważona zarówno przez Hülsena, jak i Stengera, doprowadziło byłego dowódcę Grupy Południe do pasji. Napisał on jeszcze jeden list do Hoefera (przekazany także ponownie do Poczdamu $)^{48}$. Uważał, że został oszukany. Pomimo wydania już w 1922 roku książki przygotował nowy opis operacji z 1921 roku. Nie opublikował go jednak, ponieważ $\mathrm{w}$ momencie nagłego pogorszenia się stosunków polsko-niemieckich ambasador niemiecki w Warszawie von Moltke poradził mu wstrzymanie druku. W tym samym czasie natomiast zostało wydane opracowanie Hoefera, co w ocenie Hülsena było niehonorowe i świadczyć miało o nierównym potraktowaniu obu oficerów (jak pisał Hülsen: „walczymy nierówną bronią”). Obiecywał, że rozprawi się z kłamstwami i nieścisłościami zawartymi w książce Hoefera ${ }^{49}$. Dowódca Grupy Południe podkreślał, że jego plan przedstawiony 20 maja był klarowny i wykorzystywał tę samą metodę, jaką w pierwszym etapie powstania zastosowali skutecznie Polacy przy bierności MKRiPleb, czyli zaskakujące jednorazowe uderzenie na wielką skalę. Obejmował on trzy etapy: 1) poszerzenie przyczółka za Odrą;

\footnotetext{
${ }^{47}$ „Der Krieg ist eine bloße Fortsetzung der Politik mit anderen Mitteln”. C. Clausewitz, Vom Kriege, Bd. 1, Berlin 1832-1834, Kapitel 1, Abschnitt 24.

${ }^{48}$ BA MA, RH 61, sygn. 17, k. 102-104, B. v. Hülsen, Berlin, den 19.2.39 (Abschrift).

${ }^{49}$ Ibidem, k. 102.
} 
2) wypchnięcie powstańców polskich z rejonu Góry św. Anny; 3) po sukcesie w realizacji dwóch pierwszych celów, mniej więcej trzy dni później, po przeformowaniu oddziałów, wydanie rozkazu o marszu kilku kolumn w kierunku górnośląskiego okręgu przemysłowego ${ }^{50}$.

Hülsen pisał w liście, że bezwarunkowa chęć Francuzów „do umierania za Polaków" była już wtedy tylko blefem, mimo incydentów podczas konfrontacji pomiędzy oddziałami Selbstschutzu a oddziałami francuskimi w Ozimku/Małejpanwi i koło Ujazdu. Gdyby jednak w czasie marszu do Gliwic doszło do kolejnego starcia, to oczywiście nie nakazałby posuwania się dalej. W takim jednak wypadku obszar kontrolowany przez Niemców (późniejsza linia rozgraniczenia) byłby i tak znacznie większy i zdecydowanie dalej wysunięty na wschód. Złożenie broni przez oddziały Selbstschutzu miałoby przy tym honorowy przebieg, bo dokonano by go po zwycięskiej operacji, a nie bez walki i chociaż próby realizacji celu, jaki sobie postawiono w momencie formowania niemieckiej Samoobrony - czyli wyparcia polskich powstańców z Górnego Śląska.

Hoefer natychmiast odpowiedział listownie swojemu oponentowi, powtarzając argumenty, które podawał wcześniej. Tym razem przyznawał jednak otwarcie, że decydujące wówczas dla niego były względy polityczne, i to nie tylko te związane z Górnym Śląskiem: „W ówczesnej sytuacji Niemiec [...] popełnienie błędu byłoby na dziesięciolecia, a nawet na stulecia szkodliwe. Chodziło zresztą nie tylko o zajęcie Zagłębia Ruhry [przez Francuzów - R.K.], jak wcześniej wielokrotnie to podkreślano, ale także o całość ostatecznie niezrealizowanych francuskich celów wojennych, takich jak: granica na Renie, na linii Menu itd." ${ }^{51}$. Nietrudno w tym wyjaśnieniu dostrzec nie tylko historyczną, lecz także bieżącą polityczną argumentację ukształtowaną pod wpływem nowej sytuacji międzynarodowej i wyraźnego już napięcia w stosunkach z Francją, co pięć miesięcy później zakończy się wybuchem II wojny światowej. Dalszą dyskusję między oficerami przerwała śmierć Hoefera w maju 1939 roku.

Dodatkowym elementem prawie trzyletniego sporu niemieckich dowódców jest zadziwiająca paralela, jaką można dostrzec pomiędzy polskimi a niemieckimi ocenami bitwy o Górę św. Anny, dotycząca sporów toczonych dzisiaj nadal przez historyków: czy dla ostatecznego rozwiązania przyjętego jesienią 1921 roku kluczowe były wydarzenia o charakterze politycznym, czy wojskowym. Po polskiej stronie konsekwentnie konieczność znalezienia rozwiązania politycznego, ze zręcznie wykorzystywanymi w 1920 i w 1921 roku wspierającymi te plany demonstracjami wojskowymi, głosił Wojciech Korfanty, mający za sobą nieoficjalne wsparcie rządu polskiego. Po stronie niemieckiej podobne stanowisko dostrzeżemy w działaniach

\footnotetext{
${ }^{50}$ Ibidem, k. 104.

${ }^{51}$ BA MA, RH 61, sygn. 17, k. 118-119, K. Hoefer an Generalleutn. Hülsen, Würzburg, den 7. März 1939.
} 
Hoefera, popieranego przez rząd Rzeszy Niemieckiej. Z kolei do rozwiązania militarnego, doprowadzenia do sytuacji faktów dokonanych dążyli głównie dowódcy wojskowi. Po stronie polskiej byli to przede wszystkim stojący na czele powstańczej Grupy Wschód Karol Grzesik, Michał Grażyński czy Jan Ludyga-Laskowski; po stronie niemieckiej - Hülsen i oficerowie jego sztabu.

W odniesieniu do bohaterów artykułu - Hülsen pozostał przekonany o tym, że MKRiPleb po 3 maja traktowała Polaków jako powstańców, w związku z czym nie mogli oni już liczyć na wsparcie z jej strony. Po zdobyciu Masywu Chełmskiego sytuacja Polaków, jego zdaniem, była rozpaczliwa: nie było możliwości oporu polskich powstańców wobec zdecydowanej ofensywy Selbstschutzu, a Polska nie była gotowa do bezpośredniej interwencji wojskowej (wojny polsko-niemieckiej) ze względu na stanowiska rządów Anglii i Włoch ${ }^{52}$.

„Polityk" Hoefer tę samą sytuację widział odmiennie. Jego zdaniem, po atakach 21 maja i 3-4 czerwca groźby MKRiPleb nie były blefem ${ }^{53}$. Ironicznie podsumował optymizm Hülsena, wykorzystując jego własną opinię wyrażoną po opublikowaniu książki Hoefera w czasopiśmie „Schlesische Monatshefte” (w maju 1938 roku Hülsen napisał krytyczny artykuł pt. Dichtung, Irrungen, Gedächtnisverschiebungen, Autosugestive Illusionen - „Poezja, błędy, zmiany w pamięci, autosugestywne złudzenia”) ${ }^{54}$. Hoefer stwierdził złośliwie, że to nie on, lecz „dowódca wojskowy” Hülsen w swoich tekstach używa takich poetyckich i wskazujących na demencję pseudoargumentów.

Spór Hoefera z Hülsenem jest jeszcze jednym dowodem na to, jak skomplikowana jest w praktyce realizacja celów politycznych środkami militarnymi oraz jak trudno przewidywać i kontrolować takie operacje, kiedy są już w trakcie realizacji. Brak koordynacji działań wojskowych i politycznych uniemożliwił Niemcom w 1921 roku wykorzystanie zwycięstwa w bitwie o Górę św. Anny, a Polsce otworzył drogę do korzystnego podziału terenu plebiscytowego.

\section{Bibliografia}

Bartsch H., Geschichte Schlesiens. Land unterm schwarzen Adler mit dem Silbermond. Seine Geschichte, sein Werden, Erblühen und Vergehen, Augsburg 1985 (2. Auflage - Würzburg 1985).

Biały F., Powstania śląskie w perspektywie czterdziestolecia, „Zaranie Śląskie” 1961, z. 4, s. 840-841. Clausewitz C., Vom Kriege, Bd. 1, Berlin 1832-1834.

${ }^{52}$ BA MA, RH 61, sygn. 17, k. 108, B. v. Hülsen, Berlin, den 19.2.39 (Abschrift).

53 BA MA, RH 61, sygn. 17, k. 110-124, K. Hoefer an Generalleutn. Hülsen, Würzburg, den 7. März 1939.

${ }^{54}$ Ibidem, k. 112. 
Eichner K., Briten, Franzosen und Italienern in Oberschlesien. Die Interaliierte Regierungs- und Plebiszitskommission in Spiegel der britischen Akten, St. Katharinen 2002.

Eiden B., Die Operation „Tannenberg”. Das letzte größere Gefecht des oberschlesischen Selbstschutzes am 4. Juni 1921, „Schlesien” 1981, Nr. 26, s. 89-98.

Eiden M., Masnyk M., Góra św. Anny, w: Historia Górnego Śląska. Polityka, gospodarka i kultura europejskiego regionu, red. J. Bahlcke, D. Gawrecki, R. Kaczmarek, Gliwice 2011, s. 439-448.

Fuchs K., Vom deutschen Krieg zur deutschen Katastrophe (1866-1945), w: Deutsche Geschichte im Osten Europas. Schlesien, hrsg. N. Conrads, Berlin 1994.

Grażyński M., Walka o Śląsk (fragmenty wspomnień) sierpień 1920-czerwiec 1921, Katowice 1931.

Grażyński M., Walka o Ślask (fragmenty wspomnień), „Powstaniec Śląski” 1936, nr 5, s. 5-8.

Haubold Stolle J., Der heilige Berg Oberschlesiens. Der Sankt Annaberg als Erinnerungsort, w: Schlesische Erinnerungsorte, hrsg. M. Czapliński, H.-J. Hahn, T. Weger, Görlitz 2005, s. 201-220.

Haubold Stolle J., Góra św. Anny - sporne serce Górnego Śląka, w: Leksykon mitów, symboli i bohaterów Górnego Śląska XIX-XX wieku, red. B. Linek, A. Michalczyk, Opole 2015, s. 397-399.

Heydebreck P., Wir Wehr-Wölfe, Leipzig 1931.

Hoefer K., Oberschlesien in der Aufstandszeit 1918-1921. Erinnerungen und Dokumente, Berlin 1938.

Hülsen B. v., Der Kampf um Oberschlesien. Oberschlesien und sein Selbstschutz, Stuttgart 1922.

Hülsen Bernhard von, Das Bundesarchiv: Akten der Reichskanzlei. Weimarer Republik online, Biographien, https://www.bundesarchiv.de/aktenreichskanzlei/1919-1933/0000/adr/adrhl/kap1_1/ para2_355.html (dostęp: 10.3.2021).

Kaczmarek R., Powstania ślaskie 1919-1920-1921. Nieznana wojna polsko-niemiecka, Kraków 2019.

Kaczmarek R., Straż Graniczna (Grenzschutz), w: Słownik powstań śląskich, t. 1: I powstanie śląskie sierpień 1919, red. M. Fic, R. Kaczmarek, Katowice 2019, s. 287-289.

Katsch H., Der oberschlesische Selbstschutz im dritten Polenaufstande, Berlin-Leipzig 1921.

Krzyk J., Szmatloch B., Korfanty, silna bestia, Katowice 2020.

Kwiatek A., Walki w rejonie Góry św. Anny w 1921 r., w: Szkice z dziejów Leśnicy, red. F. Hawranek, Opole 1977, s. 91-107.

Lesiuk W., Hoefer Karl Julius Robert, w: Encyklopedia powstań śląskich, red. F. Hawranek et al., Opole 1982, s. 172.

Ludyga-Laskowski J., Zarys historįi trzech powstań śląskich, 1919 - 1920 - 1921, Warszawa-Wrocław 1973.

Mielżyński M. (Nowina-Doliwa), Wspomnienia i przyczynki do historji III-go powstania górnoślaskiego, Mikołów 1931.

Mohaupt A., Kampf um den Annaberg. Tagebuch eines Sekundaners, Berlin 1936.

Oertzen W. v., W. Petersen, Kamerad, reich mir die Hände. Freikorps und Grenzschutz, Baltikum und Heimat, Berlin 1933.

Popiołek K., Trzecie powstanie śląskie, Katowice 1946 (wyd. 2 - 1971).

Popiołek K., Historia Ślaska od pradziejów do 1945 roku, Katowice 1972 (wyd. 2 popr. - 1979).

Ryżewski W., Organizacja i rola sztabów powstańczych w III powstaniu śląskim, „Studia i Materiały z Dziejów Śląska" 1963, nr 5, s. 481-504.

Ryżewski W., Trzecie powstanie ślaskie 1921. Geneza i przebieg działań bojowych, Warszawa 1977.

Salomon E. v., Das Buch vom deutschen Freikorpskämpfer, Berlin 1938.

Schmidt H.T., Karl Hoefer, „Der Oberschlesier” 1939, Nr. 9, s. 473-475.

W.K., General Hoefer, „Der Oberschlesier” 1939, Nr. 5, s. 309.

Wrzosek M., Bitwa pod Góra św. Anny, 21 V-4 VI 1921, „Mówią Wieki” 1966, nr 9, s. 16-20.

XX, Bernhard v. Hülsen, „Schlesische Stimme” 1940, Nr. 5-6, s. 216.

Zitt H., Sturm auf den Annaberg. Mit dem Freikorps Oberland in Oberschlesien, Götersloh [1933]. 
Ryszard Kaczmarek

\section{Politicians and Soldiers. The Dispute between Karl Hoefer and Bernard Hülsen over the Significance of the Battle of St. Anne's Mountain during the Third Silesian Uprising in 1921}

Summary

After World War I, a conflict broke out between Poland and Germany over Upper Silesia. It was to be settled, according to the provisions of the Treaty of Versailles, by a plebiscite. However, on May 3 , 1921, the Polish uprising broke out. Insurgent troops occupied the eastern part of the plebiscite area. On May 21, 1921, German troops of the so-called Upper Silesia Self-Defense (Selbstschutz Oberschlesiens) carried out an effective counteroffensive, known as the Battle of St. Anne's Mountain. In this article, Ryszard Kaczmarek discusses the dispute that has been going on for many years among historians about who had planned and who commanded this military operation. The main opponents in this operation were: Karl Hoefer, the commander-in-chief of the Self-Defense, and Bernhard Hülsen, the commander of one of the Self-Defense's units. For many years, until the outbreak of World War II, both these officers claimed victory in the Battle of St. Anne's Mountain. On the basis of the extant correspondence stored in the military section of the Federal Archives in Freiburg, Kaczmarek reconstructs the course of events during the operation. He author shows the political conditions of military decisions and the complicated relations of the democratic government of the Weimar Republic with officers who were associated with the nationalist right.

Key word s: Upper Silesia, Selbstschutz, St. Anne’s Mountain, III Silesian Uprising, Weimar Republic, Hoefer, Hülsen, 1921 